\title{
UNBOXING NELVANA: ANIMATION CEL PRESERVATION AND STORAGE FOR THE NELVANA ANIMATION COLLECTION
}

By

Heather Tinker

BA Communication and Film Studies, Wilfrid Laurier University, 2013

\author{
A practical report \\ presented to Ryerson University \\ in partial fulfillment of the \\ requirements for the degree of \\ Master of Arts \\ in the Program of
}

Film and Photography Preservation and Collections Management

Toronto, Ontario, Canada, 2016

(C) Heather Tinker 2016 


\section{AUTHOR'S DECLARATION FOR ELECTRONIC SUBMISSION OF A PRACTICAL REPORT}

I hereby declare that I am the sole author of this practical report. This is a true copy of the practical report, including any required final revisions, as accepted by my examiners.

I authorize Ryerson University to lend this practical report to other institutions or individuals for the purpose of scholarly research.

I further authorize Ryerson University to reproduce this practical report by photocopying or by other means, in total or in part, at the request of other institutions or individuals for the purpose of scholarly research.

I understand that my practical report may be made electronically available to the public.

Signed

Heather Tinker 


\title{
Unboxing Nelvana: Animation Cel Preservation and Storage for the Nelvana Animation Collection
}

\author{
Heather Tinker \\ Master of Arts, 2016 Film and Photographic Preservation and Collections \\ Management
}

Ryerson University, Toronto, Ontario in coordination with Media Commons, University of Toronto Libraries, Toronto, Ontario

\begin{abstract}
With no concrete preservation practices in place, the conservation and preservation of animation cels is a challenge for the stewards of animation-related collections. Characterized as mixed media artefacts, animation cels fall somewhere between illustrative art and motion picture film, which partially accounts for the lack of defined guidelines. Studies researching the conservation of animation cels, such as the one conducted by the Getty Conservation Institute in collaboration with the Disney Animation Research Library are so recent that, to date, no conclusive findings have been established. This practical report focuses on the organization, conservation, and storage of the Nelvana Animation Collection housed at Media Commons, University of Toronto Libraries. The information and recommendations provided within are intended as a guide for approaching animation cel care and conservation following "best known practices." These practices include currently adopted methods of cel conservation, as well as techniques borrowed from the conservation practices of similar objects.
\end{abstract}




\section{Acknowledgments}

I would like to express my gratitude to the following people for contributing valuable information and advice to my practical report: Michael Schilling (GCI Senior Scientist), Kevin MacMillan (Manager Burbank Operations Deluxe Archive Solutions), Snowden Becker (Program Manager Moving Image Archives Studies UCLA) and her wonderful students, Katherine Allen, Caitlin Deny, and Jen O'Leary, as well as all those who very swiftly and insightfully responded to my AMIA post. Thank you very much for so generously sharing your time and expertise.

I would also like to thank my first and second readers, Alicia Fletcher of TIFF and Christina Stewart of Media Commons, University of Toronto Libraries. Alicia, thank you so much for your time and guidance. I greatly appreciate your valuable comments and kindness during this process. Christina, I am so grateful for your instruction and professional advice. Thank you both for working so hard to help me overcome some difficult circumstances and complete this final practical report.

Additional gratitude goes to my friends and family for their support and words of wisdom. A special thank you must be extended to my mother, Barb Tinker, for her unconditional love and endless patience. I can never fully express my appreciation. 


\section{Table of Contents}

\begin{tabular}{ll} 
INTRODUCTION & 1 \\
\hline
\end{tabular}

LITERATURE REVIEW $\quad 5$

$\begin{array}{ll}\text { 1.1 NELVANA } & 5 \\ 1.2 \text { CANADIAN ANIMATION HISTORY } & 6\end{array}$

1.2 CANADIAN ANIMATION HISTORY $\quad 6$

1.3 CEL ANimATION PRESERVATION $r$

1.4 ARChival Practices

CHAPTER 1: CEL ANIMATION HISTORY $\quad 15$

CHAPTER 2: CURRENT INVESTIGATION INTO ANIMATION CEL PRESERVATION 19

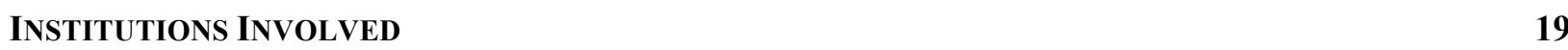

$\begin{array}{lr}\text { THE STUDY } & 20\end{array}$

CHAPTER 3: COMMON DETERIORATION OF CELLULOSE NITRATE AND ACETATE 21

CHAPTER 4: NELVANA $\quad 23$

HISTORY $\quad 23$

THE COLLECTION

CHAPTER 5: LIMITATIONS AND METHODOLOGY $\quad 28$

CHAPTER 6: CURRENT BEST PRACTICES FOR ANIMATION CEL PRESERVATION 30

FIRST STEPS FOR THE NELVANA COLLECTION

HANDLING

CLEANing $\quad 36$

$\begin{array}{lr}\text { HOUSING } & 37\end{array}$

ORIENTATION

VOLUME

CHAPTER 7: STORAGE SOLUTIONS $\quad 45$

$\begin{array}{ll}\text { STORING NELVANA } & 57\end{array}$

\begin{tabular}{lr} 
CHAPTER 8: NEXT STEPS & 59 \\
\hline
\end{tabular}

CHAPTER 9: CONCLUSION $\quad 63$

CONTACTS AND RESOURCES $\quad 65$

ANIMATION CONSERVATION

$\begin{array}{lr}\text { STORAGE } & 65\end{array}$

\begin{tabular}{ll} 
BIBLIOGRAPHY & 67 \\
\hline
\end{tabular} 


\section{Table of Figures}

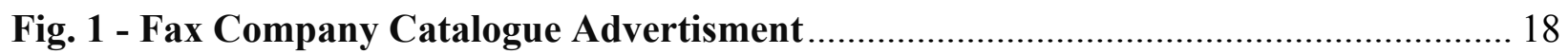

Fig. 2 - Framed Animation Cel and Background ………………….................................. 38

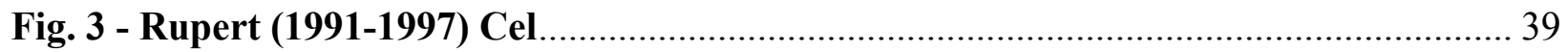

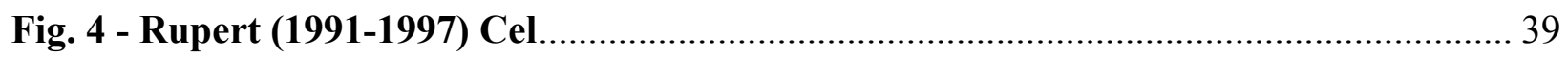

Fig. 5 - Opening Credit Cel from Mr. Pencil Draws the Line (n.d.) ……………………..... 41

Fig. 6 - The Care Bears (1985-1988) Cel ............................................................................... 43

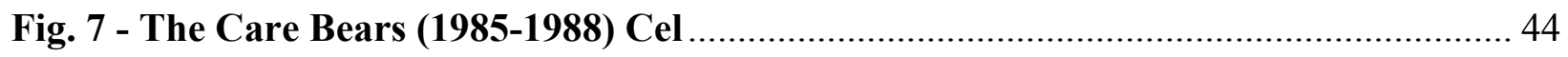

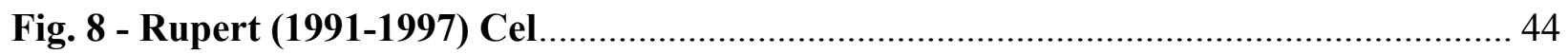

Fig. 9 - Gaylord ${ }^{\circledR}$ 1-Compartment Archival Artifact Tray …………………….................... 46

Fig. 10 - Archival ${ }^{\circledR}$ Classic Record Storage Carton with Handholds..................................... 46

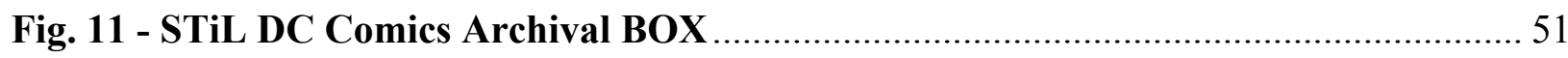

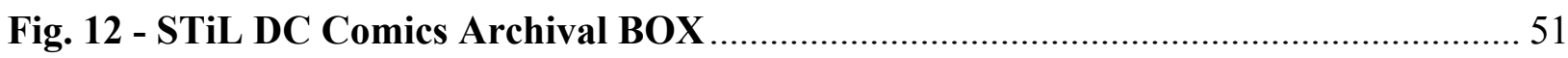

Fig. 13 - STiL Casing Solutions Promotional Materials ...................................................... 52

Fig. 14 - Hollinger Metal Edge Range of Drop Front Boxes .............................................. 54

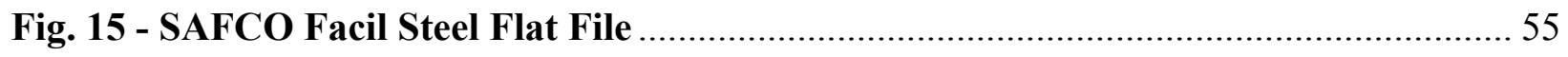

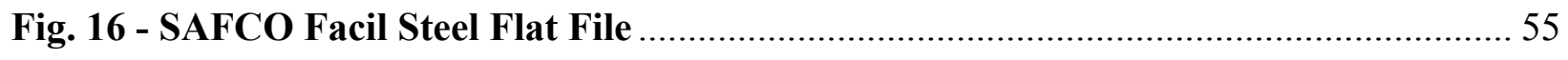

Fig. 17 - The Mayline 10-Drawer Steel C-File with Flush Base............................................ 56

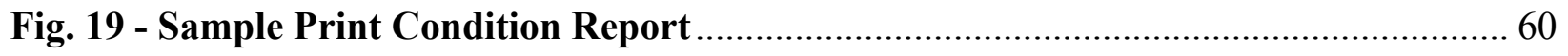

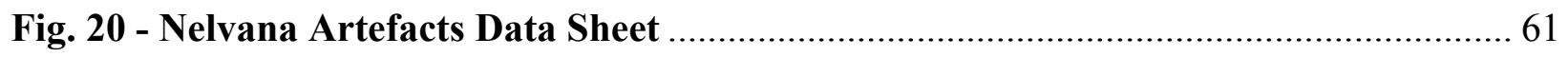




\section{Introduction}

Once upon a time animation art wasn't worth the celluloid it was painted on. ${ }^{1}$

Today the cultural and historical value of animation collections is much higher than that of the celluloid that bears original animation art. The process of hand drawn cel animation is as much about the celluloid used to create the motion picture as it is about the film used to project it. While the history of film preservation is still being written, the preservation of animation has largely been left out of current rhetoric related to the preservation and storage of the moving image. Film preservation is complicated by the multiple media assembly of artefacts used to create a motion picture. I believe that the artefacts instrumental in the production of an animated motion picture are essential to the preservation of a component that informs animation's industrial history. The focus of this paper is on the organization, conservation, and storage of the Nelvana Animation Collection currently housed at Media Commons, University of Toronto Libraries. Nelvana, a Canadian animation company that specializes in children's television, international co-productions, and adaptations, produced thousands of classic hand-drawn animation cels, pencil drawings, and pieces of background art throughout the company's fortyyear history.

Set designs, costumes, props, characters, and backgrounds are featured within animation cels. An animation cel, the hard copy of an animated film prior to its photography, should be considered an essential original document to the same degree as an animated film's negative. In many cases, including examples from the silent era, all that remain of lost films are written

\footnotetext{
${ }^{1}$ Joe Strike, "From Disney to Ground Zero and Beyond - The Ron Barbagallo Interview," Animation World Network, January 31, 2011, accessed May 17, 2016, http://www.awn.com/blog/disney-groundzero-and-beyond-ron-barbagallo-interview.
} 
accounts, such as reviews, scripts, and suggested accompanying scores. Animation cels offer more than a written account. They represent, frame by frame, the visual character of the motion picture. Cel animation was the dominant form of animation until the advent of digital animation. With the current dominance of digital animation, we are losing the history of traditional forms and processes of animation. Animation cels are art; they are also visual evidence of the time and work invested in the creation of a moving image. I believe the main challenges of animation preservation come from animation cels falling somewhere between illustrative art and film. Unlike the preservation of a piece of artwork, such as a drawing, preserving film-related artefacts can include the preservation of objects, documentation, and mixed media. Film production materials and documentation can be used in exhibitions, historical research, and education. Film cels are the perfect material to illustrate the mechanical process of creating a classic hand-drawn animated motion picture.

The preservation and conservation of plastic materials such as celluloid, used to create animation cel sheets, is an ongoing challenge for museums, archives, and libraries. Large scale research into animation cel conservation is a recent venture in the field. In this paper I explore best known practices for preserving animation cels. For the purposes of this paper, "best known practices" refers to the tools, techniques, and methods currently adopted by institutions charged with the stewardship of cel animation art. "Best known practices" also encompasses processes used for the conservation and preservation of motion picture film and plastic museum objects, which can also be applied to animation preservation as they are similar objects. Additionally, I outline some of the research recently conducted on cel animation stability and durability. Other areas of research I consulted include the degradation of plastics, motion picture film, and mixed media artefacts. Most notably, I draw upon the research produced by the partnership between the 
Disney Animation Research Library (ARL) and the Getty Conservation Institute (GCI). The ARL and GCI partnership focuses on identifying chemical properties and degradation in both nitrate and acetate animation cels. Other organizations, such as the International Animation Film Society (ASIFA) are contributing to animation preservation by utilizing alternative methods. By collecting animated film materials and raising money for their preservation, the ASIFA is ensuring that these artefacts survive the period during which proper preservation and storage strategies are still being developed. The ASIFA is currently working on their Animation Preservation Project with the University of California, Los Angeles (UCLA).

In this paper, I characterize the Nelvana Collection and describe the animation process, the materials involved in cel animation, archival practices, and current best known practices for animation cel conservation. In addition, I summarize the limitations I encountered while researching and preparing my practical report. My recommendations for Media Commons on the preservation and handling of animation cels within their Nelvana Animation Collection can be found throughout this paper. Due to their ephemeral nature, animation cels were not designed to last. Celluloid animation sheets are made from a combination of self-destructing materials, plastics, and paints.

The purpose of this practical report is to identify the gaps in available animation cel preservation information, address the difficult and unique aspects of preserving animation cels, and to gather current methods used for conservation by archivists and private conservators, as well as borrow techniques from established conservation practices for similar materials, such as motion picture film and plastic artefacts. This practical report is meant to inform archivists, collections managers, and even private collectors on the methods and techniques currently available to help prolong the life of animation cels so that they may be safely exhibited, studied, 
or otherwise utilized currently and in the future. It is time to be excited and concerned for animation preservation. 


\section{Literature Review}

\subsection{Nelvana}

The material subjects for this practical report are drawn from the Nelvana Animation Collection. Nelvana is a Canadian animation company founded in 1971 by Michael Hirsh, Patrick Loubert, and Clive Smith. ${ }^{2}$ Daniel Stoffman's book, The Nelvana Story: Thirty Animated Years, ${ }^{3}$ has been a valuable resource, as it is the only book dedicated specifically to Nelvana. Stoffman's book recounts Nelvana's origins and provides a detailed history of the company. The book is divided by decade from the 1970s through the 1990s and includes many images of the founders, animation teams, production art, and ephemera. Sources specifically written about Nelvana are limited. Two articles, "Nelvana 30th Anniversary Profile"4 by James Fitzgerald and "Three Men and a Bear: Nelvana at 25"5 by Marc Glassman, profile the company’s founders, outline brief histories of Nelvana, and detail how it grew significantly over the years. Both articles highlight the company's success in producing children's animated television content. The authors also specifically champion Nelvana's early holiday specials, such as A Cosmic Christmas (1977) and The Devil and Daniel Mouse (1978), as well as their forays into animations targeted at adult audiences, including Rock and Rule (1983) and television series such as Bob and Margaret (1998-2001).

While sources dedicated exclusively to Nelvana are scarce, comprehensive texts on animation and animated television include Nelvana and its works. Karen Mazurkewich’s

\footnotetext{
2 James Fitzgerald, "Nelvana 30th Anniversary Profile," Kidscreen, May 1, 2001, accessed November 1, 2015, http://kidscreen.com/2001/05/01/30888-20010501/, 21-22.

${ }^{3}$ Daniel Stoffman, The Nelvana Story: Thirty Animated Years, (Toronto: Kids Can Press, 2002).

${ }^{4}$ James Fitzgerald, "Nelvana 30th Anniversary Profile," Kidscreen, May 1, 2001, accessed November 1, 2015, http://kidscreen.com/2001/05/01/30888-20010501/, 21-22.

${ }^{5}$ Marc Glassman, "Three men and a bear: Nelvana at 25," The Free Library, 1996, accessed October 14, 2015, http://www.thefreelibrary.com/Three men and a bear: Nelvana at 25.-a030533629.
} 
Cartoon Capers: The History of Canadian Animators ${ }^{6}$ provides a history of Canadian animation and discusses important but lesser known players in the industry. This text profiles filmmakers such as Richard Condie, as well as internationally recognized animation pioneers including Norman McLaren. Unfortunately, Mazurkewich's book focuses more on Canadian animators working abroad on non-Canadian productions than on homegrown works. In the same vein, America Toons In: A History of Television Animation, written by Canadian author David Perlmutter, provides a detailed history of animated television. ${ }^{7}$ While Perlmutter's book focuses on animated television in the United States, the author nevertheless champions Nelvana as a creative hub and dominant force in the animation industry. Perlmutter references Nelvana in several instances throughout the text, characterizing the studio as retaining its own identity while successfully piloting co-productions within the United States and abroad.

\subsection{Canadian Animation History}

For general histories of animation, Paul Wells' book Understanding Animation ${ }^{8}$ is a valuable text, as it provides definitions and context for animation. Wells utilizes Norman McLaren's notion that the significance of animation lies in the detailed activity that occurs between each shot. ${ }^{9}$ We are encouraged to appreciate individual animation cels, hand-drawn or scratched images, and movements of clay or paper. Wells emphasizes the importance of these film-related materials as the bricks used to build the film. In a collection comprised largely of animation cels and background art, this concept is paramount.

\footnotetext{
${ }^{6}$ Karen Mazurkewich, Cartoon Capers: The History of Canadian Animators (Michigan: University of Michigan, 1999).

${ }^{7}$ David Perlmutter, America Toons In: A History of Television Animation (North Carolina: McFarland and Company Inc., 2014).

${ }^{8}$ Paul Wells, Understanding Animation (London; New York: Routledge, 1998).

${ }^{9}$ Ibid. 10.
} 
Sources that focus more specifically on Canadian content include Chris Robinson's "English-Canadian Animation 1975-2000."10 This article looks at how animation developed in different areas of the country, specifically Winnipeg, Vancouver, Ottawa, Toronto, and Halifax. Robinson discusses Canada as a leading pioneer in computer-animated software and techniques. Robinson also describes the shift from government-funded animation to a market-driven industry in global entertainment, of which Nelvana is cited as a prime example. ${ }^{11}$ The author highly praises Nelvana's unique and diverse styles of animation across their different projects. In the book Canadian Television: Text and Context, ${ }^{12}$ chapters such as "(Who Knows?) What Remains to Be Seen: Archives, Access, and Other Practical Problems for the Study of Canadian 'National' Television" by Jennifer VanderBurgh and "Hypercommercialism and Canadian Children's Television: The Case of YTV" by Kyle Asquith place animation within a national framework. Asquith focuses on the hypercommercialism and advertising embedded in children's television, referencing Nelvana productions and providing much needed context. Some of Nelvana's productions were originally based on popular children's products such as The Care Bears Movie (1985), Beyblade (2001-2005), and Madballs: Gross Jokes (1987). VanderBurgh's article criticizes the lack of access to or availability of television archives and collections for researchers and the public. She cites the Canadian Broadcasting Corporation's (CBC) closed archive as a representative challenge. VanderBurgh also feels that productions and distribution methods are

\footnotetext{
${ }^{10}$ Chris Robinson, "English-Canadian Animation 1975 - 2000," in English-Canadian Cinema since 1980, (Edmonton: University of Alberta Press, 2002).

${ }^{11}$ Ibid. 65.

${ }^{12}$ Marian Bredin, Scott Henderson, and Sarah A. Matheson, Canadian Television: Text and Context, (Waterloo, Ontario: Wilfrid Laurier University Press, 2011).
} 
heavily subsidized by the government, and therefore should be more widely accessible to Canadians. ${ }^{13}$

Finally, Canadian Content in the 21st Century in Film and Television Productions: A Matter of Cultural Identity ${ }^{14}$ by Francois N. Macerola and Canadian Heritage defines the specific qualifications that make a production Canadian. This book includes charts and a points system to determine if the production is Canadian. This source is particularly valuable because the book includes a section outlining the criteria for animated productions including roles specific to animation such as 'key animator' and 'first or second voice.' The book also provides criteria for series works, such as children's animated television shows, as well as co-ventures defined as international co-productions, of which Nelvana has produced many. The criteria outlined in this text can be used to determine what does or does not constitute Canadian content, regardless of the partnership of a co-producing country.

\subsection{Cel Animation Preservation}

I have been guided primarily by two papers in structuring my practical report. The first is Karen Hong Saracino's Animation Cel Storage and Preservation: Caring for a Unique American Art Form. ${ }^{15}$ Hong Saracino's paper compiles information on animation cel preservation and steps that can be taken to delay deterioration. The second is Proposal for Equipment, Policies, and

\footnotetext{
${ }^{13}$ Jennifer VanderBurgh, "(Who Knows?) What Remains to Be Seen: Archives, Access, and Other Practicle Problems for the Study of Canadian "National" Television," Canadian Television: Text and Context (Waterloo, Ontario: Wilfrid Laurier University Press, 2011), 41.

${ }^{14}$ Francois N. Macerola, and Canada. Canadian Heritage, Canadian Content in the 21st Century in Film and Television Productions: A Matter of Cultural Identity (Hull, Quebec: Canadian Heritage, 2003).

${ }^{15}$ Karen Hong Saracino, "Animation Cel Storage and Preservation: Caring For a Unique American Art Form,” (MA diss., John F. Kennedy University, 2006).
} 
Procedures to Ensure the Safety of Nickelodeon's Assets in the New Archival Space ${ }^{16}$ written by Katherine Allen, Caitlin Deny, and Jen O'Leary. This paper is a guide for handling and storing animation cels, including climate control guidelines. Both papers have also pointed to further resources on animation cel preservation and management compiled for existing collections of animation cels.

I looked to the following sources for a better understanding of the conservation and deterioration of animation cels and closely related materials, such as motion picture film and other vulnerable plastics in archival collections. In his article "Mickey, Donald, Goofy \& Pluto What's Breaking Up That Old Gang of Mine?: A Quantitative Look at the 'Cel' Art Created for Walt Disney's Animated Films and Its Deterioration Process, ${ }^{, 17}$ conservationist Ron Barbagallo describes the history of cel animation as well as his own animation cel conservation techniques and experiences. Richard Kroon describes typical characteristics of animation cels and their lack of inherent longevity in his book $A / V A$ to $Z$ an Encyclopedic Dictionary of Media, Entertainment and Other Audiovisual Terms. ${ }^{18}$ For example, Kroon provides dimensions and physical descriptions typical of most animation cels. He also provides animation production histories including the practice of washing cels to be reused.

\footnotetext{
${ }^{16}$ Katharine Allen, Caitlin Denny, and Jen O'Leary, "A Proposal for Equipment, Policies, and Procedures to Ensure the Safety of Nickelodeon's Assets in the New Archival Space," (MA diss., University of California, 2006).

${ }^{17}$ Ron Barbagallo, "Mickey, Donald, Goofy \& Pluto What's Breaking Up That Old Gang of Mine?: A Quantitative Look at the 'Cel' Art Created for Walt Disney's Animated Films and Its Deterioration Process," Topics in Photographic Preservation 6 (1995): 98-105.

${ }^{18}$ Richard W. Kroon, A/V A to Z an Encyclopedic Dictionary of Media, Entertainment and Other Audiovisual Terms (Jefferson, N.C.: McFarland \& Co, 2010).
} 
In Richard Larson and Eric J. Weber's "Hydrolysis," Reaction | Chemical Reaction, ${ }^{20}$ and Yvonne Shashoua's "Inhibiting the Inevitable: Current Approaches to Slowing the Deterioration of Plastics," 21 the authors outline the process of cellulose nitrate and acetate deterioration. Eventually, cellulose acetate was replaced in animation by mylar polyester "cels." However, because many artists preferred the relationship of paint and cellulose acetate over the use of polyester, the use of cellulose acetate in animation persisted. $^{22}$ Therefore it is not guaranteed in animation that, by a certain date or date range, a new material base would be used for production cels.

To adequately inform collections managers, registrars, and institution staff about best methods for the preservation and storage of animation cel art, I have compiled different sources related to mixed media and film preservation, as well as materials on the preservation of plastic objects. I have also focused on some key texts that outline the work and findings of a collaboration effort by the Disney Animation Research Library (ARL) and the Getty Conservation Institute (GCI). A key text in my research has been "Characterization of Chemical and Physical Properties of Animation Cels from the Walt Disney Animation Research Library." 23 This paper describes the 2009 partnership of the ARL and the GCI. The study was

\footnotetext{
${ }^{19}$ Richard A. Larson, and Eric J. Weber, "Hydrolysis," Reaction Mechanisms in Environmental Organic Chemistry (Boca Raton: Lewis Publishers, 1994).

${ }^{20}$ Graham R. Fleming, "Photochemical Reaction | Chemical Reaction," Encyclopedia Britannica, Accessed April 25, 2016, http://www.britannica.com/EBchecked/topic/457736/photochemical-reaction.

${ }^{21}$ Yvonne Shashoua, "Inhibiting the Inevitable; Current Approaches to Slowing the Deterioration of Plastics," Macromolecular Symposia 238 (April 2006): 67-77.

${ }^{22}$ Miriam T. Giachet, Michael Schilling, Kristen McCormick, Joy Mazurek, Emma Richardson, Herant Khanjian, and Tom Learner, "Assessment of the Composition and Condition of Animation Cels Made from Cellulose Acetate," Polymer Degradation and Stability 107 (Spring 2014): 1.

${ }^{23}$ M.T. Giachet, Michael Schilling, Joy Mazurek, Emma Richardson, C. Pesme, Herant Khanjian, Tom Learner, and Kristen McCormick. ed. J. Bridgland, Art, "Characterization of Chemical and Physical Properties of Animation Cels from the Walt Disney Animation Research Library," ICOM-CC 17th Triennial Conference Preprints, Melbourne 1012 (September 2014).
} 
initiated to address the preservation issues caused by the deterioration of animation art. ${ }^{24}$ The aim of this collaboration is to determine the age of the cel, the chemical and material properties of the cel, as well as the conditions in which the cels have been stored. In this study, the institutions are looking at a range of production and replica animation cels provided by the ARL. ${ }^{25}$ In alignment with the article "Assessment of the Composition and Condition of Animation Cels Made from Cellulose Acetate, ${ }^{, 26}$ the paper explores some of the first findings from the ARL and GCI project. In a recent issue of the Getty Newsletter, authors Kristen McCormick and Michael R. Schilling break down some of the scientific findings for a more general audience in their article "Animation Cel: Preserving a Portion of Cinematic History." ${ }^{27}$ It is important to be able to identify the type of materials within a collection in order to determine best practices for housing and preservation.

I have referred to sources such as Yvonne Shashoua's "Inhibiting the Inevitable: Current Approaches to Slowing the Deterioration of Plastics" ${ }^{28}$ to better understand the deterioration of plastic materials. Shashoua's paper outlines some of the main factors causing degradation of unstable plastics, as commonly seen in museum collections. The author also offers possible solutions, including the use of zeolites to inhibit the deterioration of cellulose acetate. ${ }^{29}$ Zeolites are microporous aluminosilicate minerals, commercially they are most commonly used as

\footnotetext{
${ }^{24}$ Ibid. 2.

${ }^{25}$ Kristen McCormick and Michael R. Schilling, "Animation Cels: Preserving a Portion of Cinematic History," Conservation Perspectives 29.1 (Spring 2014): 11.

${ }^{26}$ Miriam T. Giachet, Michael Schilling, Kristen McCormick, Joy Mazurek, Emma Richardson, Herant Khanjian, and Tom Learner, "Assessment of the Composition and Condition of Animation Cels Made from Cellulose Acetate," Polymer Degradation and Stability 107 (Spring 2014).

${ }^{27}$ Kristen McCormick, and Michael R. Schilling, "Animation Cels: Preserving a Portion of Cinematic History," Conservation Perspectives 29.1 (Spring 2014).

${ }^{28}$ Yvonne Shashoua, "Inhibiting the Inevitable; Current Approaches to Slowing the Deterioration of Plastics," Macromolecular Symposia 238 (April 2006): 67-77.

${ }^{29}$ Ibid. 71.
} 
absorbents, capable of absorbing excess moisture and contaminates. ${ }^{30}$ Another source on the preservation of plastic materials is the POPART project. The Preservation of Plastic ARTefacts in Museum Collections was a major international research collaboration involving twelve institutions that ran between 2008 and 2012. The project resulted in an international conference held in Paris and published conference proceedings. The book, Preservation of Plastic Artefacts in Museum Collections, ${ }^{31}$ outlines the main research areas in the conservation of plastics. The book itself is published exclusively in French, and only the accompanying website (http://popart$\underline{\text { highlights.mnhn.fr/index.html }})^{32}$ offers English translations. The website features articles and videos related to the project, which provide further insight into the identification, cleaning, and conservation of plastics. ${ }^{33}$ It is important to keep in mind that acetate-based museum objects, film, and cellulose acetate animation cels are all different and must be treated as such. Due to the fact that animation cels are similar to both film and other plastic museum objects, it is wise to review documentation on the preservation of like objects in case it proposes potential solutions to any overlapping preservation dilemmas.

\subsection{Archival Practices}

For accurate terminology, I looked at sources such as the Canadian Council of Archives' Rules for Archival Description (RAD). ${ }^{34}$ RAD is the archival description standard for Canada. RAD describes rules, concepts, and guidelines for creating a finding aid and generating archival descriptions. "Chapter 4: Graphic Materials" refers specifically to the description and

\footnotetext{
${ }^{30}$ Herman van Bekkum, Edith M. Flanigen, and J. C. Jansen, Introduction to Zeolite Science and Practice (Amsterdam: Elsevier, 1991), 11-12.

${ }^{31}$ Alban Fournier, Bertrand Lavédrine, and Graham Martin, Preservation of Plastic Artefacts in Museum Collection, (Paris: Cths Edition, 2012).

32 "Home" accessed April 27, 2016, http://popart-highlights.mnhn.fr/index.html.

33 “Overview," accessed April 2, 2016, http://www.getty.edu/conservation/about/overview.html.

${ }^{34}$ Canadian Committee on Archival Description, Rules for Archival Description, Rev. ed. (Ottawa: Bureau of Canadian Archivists, 2008).
} 
arrangement of graphic materials or "two-dimensional pictorial representations," 35 including drawings, prints, and photographs. Elements of the Nelvana collections, such as animation cels and character sketches, fall under the category of graphic materials. As the Nelvana collection contains film and videotape, "Chapter 7: Moving Images" is also necessary for the description of this collection. "Chapter 7: Moving Images" contains terminology specific to television and film.

Working on a collection with film elements requires knowledge of film preservation and archiving. A standard text for film preservation and collections management is the National Film Preservation Foundation's The Film Preservation Guide: The Basics for Archives, Libraries, and Museums. ${ }^{36}$ This guide was created by a collaboration of film preservationists and contains chapters detailing the film-making process, preservation process, acquisition, and exhibition. One of the best features of this guide is the case studies included in each chapter. Along with The Film Preservation Guide, Helen Harrison's article Audiovisual Archives ${ }^{37}$ describes moving image and sound archives as similar to other archives but with new and different challenges concerning access and preservation. Harrison describes concepts of migration and authenticity as significant issues facing audiovisual archives. The author argues in favour of a need for specialized audiovisual archives and archivists.

Finally, Preservation Management for Libraries, Archives and Museums (2006) edited by G. E. Gorman and Sydney J. Shep compiles knowledge and experience from practiced professionals. This collection of resources provides guidance on preservation methods maintaining good practices within what the authors refer to as "memory institutions," meaning

\footnotetext{
${ }^{35}$ Canadian Council of Archives, "Chapter 4: Graphic Materials," In Rules for Archival Description, Rev. ed. (Ottawa: Canadian Council of Archives and the National Archives of Canada, 2008), 4-3.

${ }^{36}$ National Film Preservation Foundation, The Film Preservation Guide: The Basics for Archives, Libraries, and Museums, (San Francisco, California: National Film Preservation Foundation, 2004).

${ }^{37}$ Helen P. Harrison, “Audiovisual Archives," Audiovisual Archives: A Practical Reader, United Nations Educational, Scientific and Cultural Organization, 1996, 1-9.
} 
museums, libraries, and archives. Along with information about memory institutions in general, I researched university libraries specifically. Edith Blendon's article, University Archives: A Reason for Existence, ${ }^{38}$ reinforces the significance of university archives and their collections. The author believes that a university archivist's purpose is to emphasize the importance of a collection, why it is valuable, and how knowledge can be acquired through accessing and studying the collection. ${ }^{39}$ This source is important to this particular kind of paper because the Nelvana collection is now housed in a collecting archive that is part of a large university library.

The research I have conducted for this paper has provided me with a greater understanding of the history and practices surrounding hand-drawn animation and the Nelvana company. Familiarizing myself with the existing information on this topic has helped me to more easily conceptualize how these materials may be used or accessed and therefore consider and develop optimal storage solutions. Now that I appreciate the popularity of Nelvana, I can infer that these materials are likely to be sought-after by researchers and library patrons. This collection is comprised of delicate materials. Policies and clear procedures around cautious handling and the use of storage containers conducive to safe retrieval should be put in place.

While sources on animation cel preservation are few, the practice is growing. Research on plastic deterioration is applicable to many archival objects, not just animation cel preservation. As archives, studios, and private collectors acquire, discover, or rediscover animation cels within their collections, it becomes increasingly necessary to gather and consolidate information and research on the preservation of animation cels. We need to share and compare, to adequately preserve and monitor these precious moving image elements.

\footnotetext{
${ }^{38}$ Edith Blendon, "University Archives: A Reason for Existence," The American Archivist 38, no. 2 (April 1975): 175-180.

${ }^{39}$ Ibid. 175.
} 


\section{Chapter 1: Cel Animation History}

Born from the development of optical toys and magic lantern shows, animated films can be described as a series of single-framed images that are typically hand-drawn. To create the illusion of motion, these constructed images are viewed in rapid succession aided by a cinematic machine, such as a television or projector. ${ }^{40}$ While there are many different techniques and materials used to produce animated films, this paper focuses on the use of cel animation. Cel animation was invented by Earl Hurd on December 19th, $1914 .{ }^{41}$ Hurd was the first person to use a very thin transparent sheet of cellulose plastic placed over top of a painted background. With the advent of animation cels it became unnecessary to redraw the entire background for each new character motion. The process of separating action images from background images allowed simple lined backgrounds to become elaborate painted scenery, which further advanced the medium. $^{42}$

To create a hand-drawn animated motion picture an artist begins by sketching the image of a character on paper. The image is then transferred to a clear sheet of cellulose nitrate, cellulose acetate, or, more recently mylar polyester. On average, each sheet measures twelve by nine inches, and is five one-thousandths of an inch thick. ${ }^{43}$ These sheets are referred to as cels (short for cellulose). The images from paper pencil drawings are then inked onto the cel, with dark paint used to define the bold lines of a character. The lines of the character or object are

\footnotetext{
${ }^{40}$ Stephen Cavalier, The World History of Animation (Berkeley, CA: University of California Press, 2011), 61.

${ }^{41}$ Ron Barbagallo, "Mickey, Donald, Goofy \& Pluto What's Breaking Up That Old Gang of Mine?: A Quantitative Look at the 'Cel' Art Created for Walt Disney's Animated Films and Its Deterioration Process," Topics in Photographic Preservation 6 (1995): 99.

${ }^{42}$ Ibid.

${ }^{43}$ Richard W. Kroon, A/V A to Z an Encyclopedic Dictionary of Media, Entertainment and Other Audiovisual Terms (Jefferson, N.C.: McFarland \& Co, 2010), 46.
} 
then filled in with coloured paint on the reverse side of the cel. Each character or object designated for motion is then photographed after it is layered on top of other cels and painted backgrounds. It is good practice to use the same number of animation sheets per frame, even if there is nothing drawn on the different layers for every scene. ${ }^{44}$ Despite the transparency and thin composition of the sheets, they are not perfectly clear; if the number of cel layers changes from scene to scene, the result would be a visible effect, obvious to the viewer. To save money on a production, animation cels would be washed in an acid bath to remove paint in order for the cellulose sheet to be reused for another scene. Typically, cels could be washed up to three times prior to deterioration becoming a concern. ${ }^{45}$ As a result, few original animation cels have survived. Therefore, more recent hand-drawn animation collections, such as the Nelvana Collection, are a rare example.

To film a classic hand-drawn animation, the different cel layers are held in place by a glass and metal frame on the desk of an animation stand like that of a rostrum camera. A rostrum camera involves a camera placed above a lit frame on a desk (figure 1). The desk is adjustable, allowing the surface to move closer or further away from the camera. The desk has metal registration pegs used to hold the animation cel in place before the metal frame is lowered to press the cel and background together in order for the shot to be exposed. The registration pegs are spaced to correspond with small holes at the bottom of each cel. This process keeps the thin sheets of paper and cellulose lined up and stationary, allowing for a clean shot and proper orientation of background and corresponding images. Attached to the back of the desk is a tall metal pole, approximately seven to eight feet in height. A motion picture camera is attached to the pole with an adjustable arm that allows the camera to zoom closer to or further from the

\footnotetext{
${ }^{44}$ Ibid.

${ }^{45}$ Ibid.
} 
frame. The rostrum camera does not have the same kind of mobility as the cinematic camera nor the later more advanced animation stands such as the multiplane camera. Therefore, any camera movement can only be along the vertical axis, moving with the camera. Movement is also possible along the horizontal axis in the form of slow pans, usually produced by sliding the animation cels or backgrounds underneath the camera. ${ }^{46}$ This type of movement required longer, and sometimes wider, animation cels or backgrounds.

${ }^{46}$ Thomas LaMarre, “Animation Stand," in The Anime Machine: A Media Theory of Animation (Minneapolis, MN: University of Minnesota Press, 2009), xxiv. 

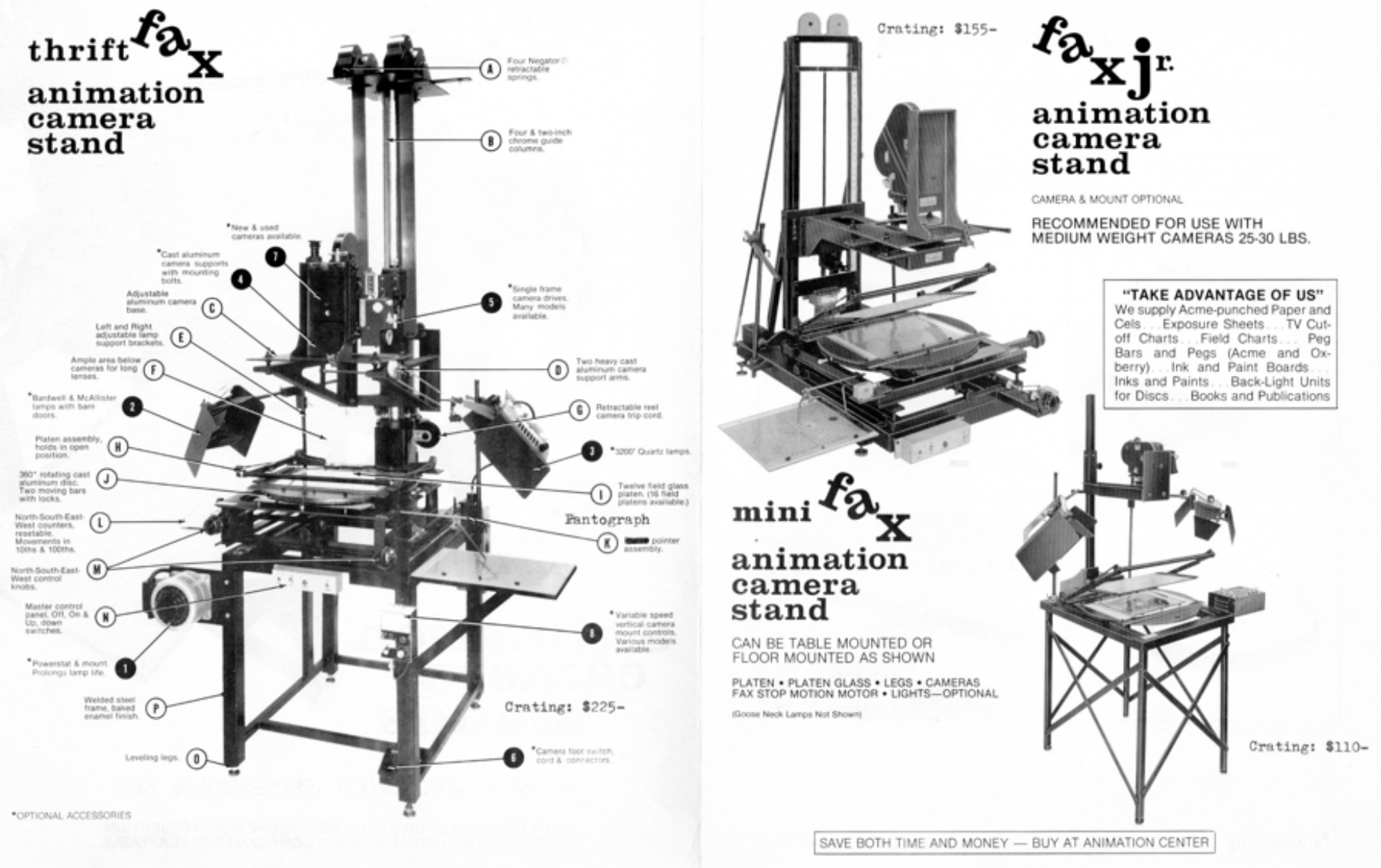

Fig. 1 - Pages from a fax company catalogue advertising three different rostrum stands. From left to right, a standard thrift fax animation camera stand, the fax jr. animation camera stand, and the mini fax animation camera stand. 


\section{Chapter 2: Current Investigation into Animation Cel Preservation}

\section{Institutions Involved}

The Walt Disney Animation Research Library houses a collection containing sixty-five million pieces of animation art and related artefacts. ${ }^{47}$ Of that staggering number, more than two hundred thousand artefacts are animation cels created between the 1920s and the 1980s. That number also includes a much smaller collection of hand-drawn polyester replica cels made later in the 1990s for commercial purposes or for traveling exhibitions. ${ }^{48}$ Other materials in the ARL collection include original animation cels and backgrounds, pencil drawings, layouts, models, conceptual design work, model sheets, exposure sheets, reference photographs, books, and audio visual materials. $^{49}$

The Getty Conservation Institute is a private non-profit organization and the authoritative voice on conservation of cultural heritage. ${ }^{50}$ The institution supports research, applied field work, education, and the dissemination of knowledge about conservation and preservation. ${ }^{51}$ In its thirty year history the Getty has branched out into four distinct areas of research and conservation; Buildings and Sites, Collections, Science, and Communications. The GCI's developments in architecture, art, photography, and, most recently, animation cel conservation have led to the creation of highly diverse preservation resources. These resources include publications, online sources, and international preservation courses. The Getty also provides students and recent graduates the opportunity to work and learn at the GCI through their

\footnotetext{
${ }^{47}$ Kristen McCormick, and Michael R. Schilling, “Animation Cels: Preserving a Portion of Cinematic History," Conservation Perspectives 29.1 (Spring 2014): 11.

${ }^{48}$ Ibid.

${ }^{49}$ Ibid.

50 “Overview," http://www.getty.edu/conservation/about/overview.html.

${ }^{51}$ Ibid.
} 
Graduate Internship Program. As a leading conservation institute with a long history situated in close proximity to the Disney Animation Research Library, the Getty is well-suited to pioneer animation cel conservation practices.

\section{The Study}

In 2009 the Disney Animation Research Library and the Getty Conservation Institute partnered to study animation cels to foster better long-term preservation practices. ${ }^{52}$ This study began as a means of addressing the preservation issues caused by the deterioration of animation art. ${ }^{53}$ The collaboration aims to determine the chemical and material properties of the cel, the age of the cel, as well as the conditions in which cels have been stored. To adequately inform collections managers, registrars, and archival staff about best methods for the preservation and storage of animation cel art, the materials and chemical stability of those materials must be properly identified. In this study the institutions looked at a range of production and replica animation cels provided by the ARL. ${ }^{54}$ In "Animation Cel: Preserving a Portion of Cinematic History, ${ }^{, 55}$ an article appearing in a 2014 issue of the Getty Newsletter, authors Kristen McCormick (Manager of Art Collections and Exhibitions at the ARL) and Michael Schilling (GCI Senior Scientist), break down some of the scientific findings for a more general audience. The first phase of the study focuses on new means of identifying the cel base. Prior to this study it was believed that animation cels were made of cellulose nitrate, polyester, or cellulose diacetate. Through minimally invasive testing, such as Fourier-transform infrared spectroscopy

\footnotetext{
${ }^{52}$ M.T. Giachet, Michael Schilling, Joy Mazurek, Emma Richardson, C. Pesme, Herant Khanjian, Tom Learner, and Kristen McCormick. ed. J. Bridgland, Art, "Characterization of Chemical and Physical Properties of Animation Cels from the Walt Disney Animation Research Library," ICOM-CC 17th Triennial Conference Preprints, Melbourne 1012 (September 2014), 2.

${ }^{53}$ Ibid.

${ }^{54}$ Kristen McCormick, and Michael R. Schilling, "Animation Cels: Preserving a Portion of Cinematic History," Conservation Perspectives 29.1 (Spring 2014): 12.

${ }^{55}$ Ibid.
} 
(FTIR), ${ }^{56}$ it was discovered that many of the Disney animation cels are in fact made of triacetate.$^{57}$ The authors argue that the discovery of the previously unknown use of triacetate, used in the making of Disney animation cels, exemplifies the need for more accessible methods of determining a cel's origins and its physical properties. ${ }^{58}$ It is important to be able to identify the type of materials within a collection in order to determine best practices for housing and preservation. Once the materials are properly identified, future phases of this collaboration will focus on how best to preserve these materials in the long term.

\section{Chapter 3: Common Deterioration of Cellulose Nitrate and Acetate}

In order to adequately maintain objects it is important to know the ways different materials in a collection can degrade, as well as the factors that inhibit or advance degradation. Nitrate can degrade through thermal, hydrolytic, and photochemical reactions. ${ }^{59}$ Thermal degradation is a chemical transformation initiated by fluctuating temperatures. Hydrolysis is the process in which a chemical transformation is caused by contact with water. ${ }^{60}$ Photochemical reactions are caused when energy is absorbed during exposure to light. ${ }^{61}$ As film deteriorates, damage can be further exacerbated when off-gassing chemical vapours are trapped with the film

\footnotetext{
${ }^{56}$ Betty Walsh, "Identification of Cellulose Nitrate and Acetate Negatives by FTIR Spectroscopy," Topics in Photographic Preservation, 6 (1995): 80.

${ }^{57}$ M.T. Giachet, Michael Schilling, Joy Mazurek, Emma Richardson, C. Pesme, Herant Khanjian, Tom Learner, and Kristen McCormick. ed. J. Bridgland, Art, "Characterization of Chemical and Physical Properties of Animation Cels from the Walt Disney Animation Research Library," ICOM-CC 17th Triennial Conference Preprints, Melbourne 1012 (September 2014), 8.

${ }^{58}$ Kristen McCormick, and Michael R. Schilling, "Animation Cels: Preserving a Portion of Cinematic History," Conservation Perspectives 29.1 (Spring 2014): 12.

${ }^{59}$ Yvonne Shashoua, "Inhibiting the Inevitable; Current Approaches to Slowing the Deterioration of Plastics," Macromolecular Symposia 238 (April 2006): 68.

${ }^{60}$ Richard A. Larson, and Eric J. Weber, "Hydrolysis," Reaction Mechanisms in Environmental Organic Chemistry (Boca Raton: Lewis Publishers, 1994), 103.

${ }^{61}$ Graham R. Fleming, "Photochemical Reaction | Chemical Reaction," Encyclopedia Britannica, Accessed April 25, 2016, http://www.britannica.com/EBchecked/topic/457736/photochemical-reaction.
} 
and not allowed to disperse. Cellulose nitrate produces nitrous oxide as it begins to degrade. The nitrous oxide gas reacts with moisture in the air and transforms into nitric acid, which is corrosive to metals and attacks organic materials such as cellulose. ${ }^{62}$

Cellulose acetate is also vulnerable to thermal, hydraulic, and photochemical reactions. However, with cellulose acetate, the primary cause of degradation is through a loss of acetyl. ${ }^{63}$ When cellulose acetate loses acetyl groups, the result is a formation of acetic acid. This process is called deacetylation, a process which is accelerated by the presence of water or acids. ${ }^{64}$ Like nitric acid, acetic acid attacks organic materials and metals. ${ }^{65}$ The chemical reactions that cause cellulose nitrate and acetate to break down present in similar ways, with symptoms including wrinkling, discolouration, and oxidization. ${ }^{66}$

In the early 1940s, cellulose nitrate used in the production of animations was replaced by cellulose acetate. Eventually in the early 1990s, acetate-based cels were replaced by polyester, which is chemically stable. For motion picture film, chemical deterioration of the gelatin layer is the primary factor promoting the deterioration of polyester film stock. ${ }^{67}$ This is not a factor that affects animation cels, as they do not have a gelatin layer. As previously stated, many artists preferred the relationship of paint and acetate over polyester, so the use of acetate cels was not

\footnotetext{
${ }^{62}$ Yvonne Shashoua, "Inhibiting the Inevitable; Current Approaches to Slowing the Deterioration of Plastics," Macromolecular Symposia 238 (April 2006): 69.

${ }^{63}$ Ibid. 70.

${ }^{64}$ Ibid.

${ }^{65}$ Ibid.

${ }^{66}$ Kristen McCormick, and Michael R. Schilling, "Animation Cels: Preserving a Portion of Cinematic History," Conservation Perspectives 29.1 (Spring 2014): 11.

${ }^{67}$ James M. Reilly, "Instructions for Using the Wheel, Graphs, and Table Basic Strategy for Film Preservation," in IPI Storage Guide for Acetate Film, edited by Karen Santoro (Image Permanence Institute: 1996), 15.
} 
fully abandoned. ${ }^{68}$ Today, most animation is created almost entirely on computers. This process no longer requires the direct interaction of plastics and paints. ${ }^{69}$

\section{Chapter 4: Nelvana}

\section{History}

A Canadian animation company that specializes in children's television, international coproductions, and adaptations, Nelvana was founded in Toronto, Ontario in 1971 by Michael Hirsh, Patrick Loubert, and Clive Smith. Enrolled in York University, Hirsh and Loubert came together over their desire to make films and a common interest in animation, as the university had no official film program at that time. ${ }^{70}$ In founding Laff Arts, their first small production company, Hirsh and Loubert joined forces with British Animator Clive Smith. Looking for an artist to develop a Laff Arts logo, Hirsh and Loubert were introduced to Smith through a mutual friend and fellow artist, Carole Pope. ${ }^{71}$ As a small company, the animators focused on the specific needs of their clients. In the late 1960s and early 1970s, clients of Laff Arts, such as the Canadian Broadcasting Corporation, were looking to produce animation. Laff Arts was able to fulfill that need. Laff Arts also began providing title animations and short Plasticine animation works for other clients such as the Ontario Education Network. ${ }^{72}$ When advertising agencies told them they liked their product but were facing trouble "selling" a company named "Laff Arts" to clients, Hirsh and Loubert knew they needed to change the company name to something that

${ }^{68}$ Miriam T. Giachet, Michael Schilling, Kristen McCormick, Joy Mazurek, Emma Richardson, Herant Khanjian, and Tom Learner, "Assessment of the Composition and Condition of Animation Cels Made from Cellulose Acetate," Polymer Degradation and Stability 107 (Spring 2014), 223.

${ }^{69}$ Kristen McCormick and Michael R. Schilling, "Animation Cels: Preserving a Portion of Cinematic History," Conservation Perspectives 29.1 (Spring 2014): 11.

${ }^{70}$ James Fitzgerald, "Nelvana 30th Anniversary Profile," Kidscreen, May 1, 2001, http://kidscreen.com/2001/05/01/30888-20010501/, 2.

${ }_{71}$ Daniel Stoffman, The Nelvana Story: Thirty Animated Years, (Kids Can Press, 2002), 15-17.

${ }^{72}$ Ibid. 18. 
would be taken seriously. ${ }^{73}$ After purchasing the rights to classic Canadian comic books, such as Johnny Canuck (1941-1946) and Nelvana of the Northern Lights (1941-1946), Hirsh, Loubert, and Smith began work on a book and traveling exhibition (supported by the National Gallery of Canada) celebrating Canadian comic books from the Second World War. The men decided to name their company Nelvana after Nelvana of the Northern Lights, a neutral and professional name with special significance to the founders, as well as significant connotations of Canadian artistic and cultural history. ${ }^{74}$

Nelvana Limited's founders did not originally intend for the company's work to specialize in animation. In the beginning, the studio intended to create live action films, which were much less expensive and time-consuming to produce. Initially, Nelvana produced small projects for TVO and fillers for the CBC. ${ }^{75}$ Television fillers are short four- or five-minute films made to fill in any dead time on air between programs. ${ }^{76}$ The difficulty in making these short films is that they have to be interesting enough to keep the viewers' attention, but not so interesting that the viewer would be disappointed when the regularly scheduled program returned. ${ }^{77}$ Nelvana's first productions were often half-animation, half-live-action hybrids, which kept costs low, yet allowed them to generate unique content. By the mid-1970s, it became clear that specializing in animation would prove lucrative for the company. ${ }^{78}$ High demand for animation, despite rumours that animation was a dying medium, found other larger studios unable to produce animation in-house. Therefore, studios looked to outsource sequences or, in

\footnotetext{
${ }^{73}$ Ibid. 19.

${ }^{74}$ Ibid. 21-22.

${ }^{75}$ Ibid. 22.

${ }^{76}$ Ibid.

${ }^{77}$ Ibid.

${ }^{78}$ Ibid. 29.
} 
some cases, entire productions. ${ }^{79}$ Already producing animation, Nelvana continued to improve their production methods in order to meet demand.$^{80}$ Experience, as well as a lack of competition from animation studios in Canada, steered the studio in the direction of full-time animation production. ${ }^{81}$ Finally, specializing in animation meant easy access to new staff through a revolving door of fresh animation talent from the new animation program at Sheridan College in Oakville, Ontario, an informal partnership and mutually beneficial relationship that still stands. ${ }^{82}$ In 1977 Nelvana produced A Cosmic Christmas, their first fully animated television special. The popularity of the space-age story detailing the meaning of Christmas led to six subsequent animated holiday specials, including an animated sequence for George Lucas' Star Wars Holiday Special (1978). ${ }^{83}$ The success of this CBC television special helped to expand the studio. Nelvana was on the rise until the commercial failure of Nelvana's first full-length animated motion picture, Rock and Rule, in 1983. The time and money lost on Rock and Rule forced the company to solicit more profitable commercial work. ${ }^{84}$ Nelvana began producing subcontracted works like Inspector Gadget (1983-1986), Strawberry Shortcake: House Warming Surprise (1983), and The Care Bears Movie (1985) for companies like American Greetings and Kerner Parker Toys. The success and revenue from The Care Bears Movie and television series launched Nelvana into the production of children's animated television - what they are most recognized for today. ${ }^{85}$ By working for producers like George Lucas and picking up subcontracted work from American Companies, Nelvana was able to accomplish what few

\footnotetext{
${ }^{79}$ Ibid.

${ }^{80}$ Ibid.

${ }^{81}$ Ibid.

${ }^{82}$ Ibid. 30.

${ }^{83}$ James Fitzgerald, "Nelvana 30th Anniversary Profile," Kidscreen, May 1, 2001, accessed November 1, 2015, http://kidscreen.com/2001/05/01/30888-20010501/, 21-22.

${ }^{84}$ Ibid. 6.

${ }^{85}$ Ibid. 6-7.
} 
Canadian studios had in the past — create a niche in the competitive U.S. television market. ${ }^{86}$ Nelvana fostered consistent high-quality programming by providing an adaptable style of animation and keeping up with new animation production technologies. ${ }^{87}$ As the leading animation studio in Canada, Nelvana was uniquely positioned to participate in international animation co-productions. Poised between the U.S. and Europe with a reputation as peacekeepers and diplomats, this Canadian studio respected cultural differences while also producing content that spoke to audiences worldwide. ${ }^{88}$ Nelvana's international work includes adapting programming from famous children's books such as Babar (1989-2000) and translating foreign animation such as the Japanese Cardcaptor Sakura (1998-200) for North American audiences. A leading company within the Canadian film industry, Nelvana's success lies not only in its rapid growth and its volume of productions, but also in the company's continued international cooperation and co-productions.

\section{The Collection}

Nelvana, Canada's largest animation studio, has produced commercials, shorts, features, and most prominently television programs. The Nelvana Animation Collection is comprised of animation production materials including animation cels, pencil drawings, background art, photographs, production documents, and audio visual elements, including 16mm motion picture film and video formats. The cels and artwork in this collection come from popular titles, such as Babar, The Care Bears (1985-1988), Rock and Rule, Rupert (1991-1997), and A Cosmic

\section{Christmas.}

\footnotetext{
${ }^{86}$ Ibid. 7.

${ }^{87}$ Ibid.

${ }^{88}$ Ibid. 11.
} 
The Nelvana Animation Collection was donated to the Art Gallery of Ontario (AGO) in 1994. Two years later, in response to Nelvana's 25th anniversary, the AGO hosted an exhibition called "Nelvana Turns 25." The exhibition displayed over eighty pieces of original artwork and cels, ranging from Nelvana's earliest television specials to later works such as Babar. Moving forward, the AGO also intended to use the Nelvana Collection for educational and family programming. Along with exhibitions of animation cels and related artwork, the AGO incorporated screenings of Nelvana films and television programs, utilizing their three theatre spaces: Jackman Hall, Rogers Theatre, and the Education Theatre. Although the Nelvana Animation Collection no longer fits with the programming at the AGO, the collection has found a new home with Media Commons, University of Toronto Libraries. Media Commons acquired the Nelvana collection at the end of February 2016. As a new addition to Media Commons, the Nelvana collection is still being processed. My work with the collection has entailed assessing the collection to determine the size and number of animation cels and artwork in order to find appropriate storage for these items.

It is difficult to say how many animation cels are in the Nelvana collection because I was not able to see the collection in its entirety. Based on the contents of the boxes I worked with and the number of similar boxes left in the collection to be surveyed, I would say that there are approximately eighty-thousand individual cels in the Nelvana collection. Of those cels, I saw an estimated $85 \%-90 \%$. As I was unable to view the entire collection, the task of providing a comprehensive overview of the work yet to be done on the Nelvana collection, and the materials and procedures involved, is difficult and problematic. For example, I do not have a sense of what other objects may have been stored with the animation cels in the collection and what their condition might be. Detecting the smell of vinegar from one box of cels would indicate that at 
least some of the cels within the box are triacetate and are starting to degrade. However, vinegar odor can transfer and linger. If these cels were stored near motion picture film elements with vinegar syndrome, it is possible that those film elements could be the source of the odor, making it difficult to know for sure the condition of the cels.

\section{Chapter 5: Limitations and Methodology}

The first and largest limitation I have faced while researching and writing this paper is a lack of time. Due to unforeseen delays, the Nelvana collection did not arrive at the University of Toronto's storage facility until well into my residency. As a result, I was not able to gather preliminary research, develop any tentative theses, or familiarize myself with the particular materials within the collection because I did not know the scope and content. The late arrival also meant that no one from Media Commons had surveyed the collection. Collectively, the delayed start, the volume of materials within the collection, and the fact that I could only visit the collection one day per week, severely compromised the writing process. After my first few visits and in consultation with my first reader, I recognized that I had to form a new project around these complicating factors and on the only materials of the Nelvana collection I have been able to access, animation cels and accompanying art.

A second major limitation to this paper is the lack of consistently and widely adopted best practices for animation cel preservation and an unwillingness to share information. A reluctance to share information by private collectors and restoration specialists about their methods is understandable given that their time-tested knowledge and techniques form the backbone of their livelihood. Lastly, I often encountered conflicting information, usually related to the different motivations for preserving animation cels. A private collector with twenty animation cels has different priorities and storage needs than an art gallery or public archive with seven-thousand 
animation cels.

The objective of my work with the Nelvana collection was to identify the production title and/or episode number associated with each object, gain an idea of the type of objects within the collection and the type of storage required to house the objects. In total, the Nelvana materials are spread across thirteen pallets. Pallets, also known as skids, are platforms usually made of wood used to move large, heavy objects and hold them off the ground. Typically, each skid holds twenty boxes full of materials. Generally, these boxes contain folders or sometimes loose piles of animation cels stacked with pencil drawings, background art, and dupe sheets. Occasionally, I might also come across story boards or character reference sheets. My research on the Nelvana studio and my own personal experience viewing Nelvana productions made it easy to identify unmarked materials. If I came across an image I could not identify, I would take pictures for reference and search the internet and The Nelvana Story: Thirty Animated Years. Due to the popularity of Nelvana productions, many images of their works are referenced on fan sites and YouTube making it easier to identify characters, research their proper names, and confirm their identities.

Unfortunately, some of these groupings of cels and backgrounds were folded, rolled, or bent in order to fit into the boxes. Unable to unfold these cels without causing more damage, I measured the bundle of cels by their longest, widest, and tallest points. I used a flexible measuring tape to estimate the size of folded cels by measuring around the edge of cels sticking out from the bundles. Other tools I brought in my kit to help measure and inspect the Nelvana animation cels included bulldog clips, which I used to clip down the box flaps while I worked on a particular box. I always had pencils and notepaper for recording my observations, as well as a felt-tip pen to label the boxes. Before I began working on any materials, I would wipe down my 
work surface with 99\% isopropyl alcohol and shop-towels. I also used cotton gloves for handling materials and non-slip moving gloves to keep a safe grip while moving boxes.

\section{Chapter 6: Current Best Practices for Animation Cel Preservation}

As unique artefacts, animation cels and related artwork are in need of proper archival care and handling. Although there is new research being conducted on the stability of animation cels, no concrete best practices have yet been established. The largest challenges facing the proper preservation of animation cels derive from the fact that they are mixed-media objects made up of celluloid and paint. Mixed-media artefacts are particularly difficult to handle and preserve because each aspect of the material reacts differently to particular storage conditions and handling methods. The recent acquisition of the Nelvana Animation Collection by Media Commons requires the conservation of a large number of animation cels and related artwork.

The materials used to create animation cels can vary. The Nelvana collection is largely made up of acetate cels. Currently, the Getty Conservation Institute and Disney Animation Research Library are working on different methods of cel base identification. What preservation practices work best for which type of material is not yet clear. Without further testing of the Nelvana cels, I have no way to discern diacetate cels from triacetate cels. Limited time and lack of ability to individually handle cels has made it difficult to say how many, if any, Nelvana cels are polyester. The chemical stability of polyester makes conservation of acetate-based cels a priority. Therefore, this paper focuses on conservation techniques for acetate film in general. The following are best known practices institutions can employ if they need to rehouse or handle acetate cels. Some techniques are borrowed from established preservation practices for different but similar materials, such as motion picture film conservation and the conservation of acetate plastic artefacts, to fill in the gaps where animation cel preservation techniques are lacking. 
Using safe storage techniques and providing a good environment are important to minimize the risk of damage to an animation cel and to prevent or delay the speed of cellulose degradation. Regulating temperature, humidity, and ventilation, and providing proper storage in breathable, accessible containers contributes to longer lasting archival materials.

The information and recommendations in this guide pertain to animation cel preservation and conservation, not restoration. Restoration involves actions taken to counterbalance any object degradation that has already taken place in order to return an artefact to its original or perceived original state. ${ }^{89}$ Preservation includes a full range of activities aimed at protecting an object while ensuring the artefact remains accessible. ${ }^{90}$ Contained within the concept of preservation as a whole, the concept of conservation encompasses all actions taken to contribute to the longevity of the artefact, as well as preventative measures that deter any further degradation. ${ }^{91}$ Conservators often specialize in conservation practices for certain types of objects. Generally, animation cel conservation methods emerge from collectors who have developed their own methods for treating animation cels. Any work that would require a conservator or animation cel specialist has been identified below. These recommendations were designed as a tentative guide for animation cel storage and handling. The following research should be utilized to improve and hopefully prolong the life of animation cels until they can be assessed by a qualified conservator or until more concrete information on cel preservation becomes available.

\footnotetext{
${ }^{89}$ The National Film and Sound Archive of Australia, "Technical Glossary // Restoration," National Film and Sound Archive, accessed August 6, 2016, http://www.nfsa.gov.au/preservation/glossary/restoration.

${ }^{90}$ National Film Preservation Foundation, The Film Preservation Guide: The Basics for Archives, Libraries, and Museums, (San Francisco, California: National Film Preservation Foundation, 2004), 3.

${ }^{91}$ The National Film and Sound Archive of Australia, "Technical Glossary // Conservation," National Film and Sound Archive, accessed August 6, 2016, http://www.nfsa.gov.au/preservation/glossary/conservation.
} 
Through e-mail and phone correspondence, the most common advice I received for working with a large quantity of animation cels is to leave the collection as it is in its current storage conditions until better preservation practices are developed. During my conversation with CGI Senior Scientist Michael Schilling, we discussed the possible ramifications of rehousing static cel collections. Unnecessary or excessive handling of any object is not ideal and can cause physical damage. It is also possible that if cels are stored with other objects, such as acidic paper materials, or stored with additional objects leading to compression of the cels, the current environmental balance captured within the boxes may encourage the chemical stability of the cels. ${ }^{92}$ While shifting the balance of their current storage conditions could aid preservation, in that cels would no longer be exposed to potentially harmful chemicals, drastic changes to the cels' environment could encourage degradation or amplify existing deterioration. ${ }^{93}$

This cautionary advice should be considered when determining the future of an animation collection. However, it is not always possible to keep cels in their current storage conditions. The environmental condition of the Nelvana collection has already been disturbed during the process of moving the materials to Media Commons. It is in the best interest of the collection and the institution to at least rehouse the cels in archival storage containers. Therefore, the collection needs to be removed from shipping boxes, assessed, catalogued, and, at the very least, rehoused in acid-free containers. As a collecting archive within a university, Media Commons is also likely to want popular materials from the Nelvana collection made accessible to their patrons as soon as possible. The following information is a general collection of guidelines and a set of recommendations for animation cel preservation. Where applicable, I have included my

\footnotetext{
${ }^{92}$ Michael R. Schilling, Phone interview, June 14, 2016.

${ }^{93}$ Ibid.
} 
recommendations for proceeding with the current best known practices for storage, housing conditions, and cel handling, specific to the Nelvana Animation Collection.

\section{First Steps for the Nelvana Animation Collection}

In tackling the animation cel component of the Nelvana collection, I believe the best course of action is to organize the cel folders into subsections. Within the Animation Cel section of the collection, cels should be separated first by production and then by episode, if the production is a series. As I have been surveying the Nelvana collection, I have kept track of production title and episode number, referred to as "sequence number" on cel folders. This will make it easier to locate separated elements from the same production. To handle the cels as little as possible and to make the process of rehousing this large collection into proper storage containers more manageable, it would be best to begin the process by working on one subsection at a time; for example, by moving all Rupert cel folders and related artwork, such as

backgrounds, from their current storage boxes into new temporary boxes to work from. Once the materials from one production are together, folders and loose papers should be organized chronologically, beginning with the earliest episode in the collection and ending with the latest. This organization process will solve two challenges posed by the collection. First, this method helps to tackle the size of the collection; as mentioned above, breaking up the re-housing process makes the workload more manageable. Second, this method provides an easy way to reincorporate elements that were separated out by the AGO for exhibition or as saleable materials.

Due to the diverse nature of the Nelvana Animation Collection, the various elements will need to be stored separately to reap the benefits of proper storage conditions for each type of material. Subsections of the collection would then be further separated by material type and size. 
All animation cels should be stored separately from paper pencil drawings and background art. At this stage, I suggest waiting for more results from animation preservation studies, such as the one conducted jointly by the ARL and the GCI. Before separating any cels from objects they are adhered to, even if it is only a few cels for exhibition or study, I advise consulting a professional conservator or animation cel specialist. ${ }^{94}$ However, if moving forward with in-house procedures for separating animation cels from paper, please see suggested guidelines under "Handling."

When rehousing the Nelvana collection, I recommend keeping objects of the same material and of the same or similar size together. While cels are generally the same width, their length can vary greatly from a standard production cel which is 12 inches $(30.5 \mathrm{~cm}) \times 9$ inches $(2$ $3 \mathrm{~cm})^{95}$ to much more sizeable background cels or cels used for tracking shots, which can be up to or longer than 40 inches $(101 \mathrm{~cm})$. For example, the production materials for Cadillacs and Dinosaurs (1993-1994) contain many oddly shaped cels and will require special consideration. Stacking longer cels with significantly smaller cels could result in bending or curving of cels, as well as chipping or cracking of the paint layers. This practice would also waste space in larger custom-made boxes that could be used to stack more of the longer cels.

\section{Handling}

As with any archival object, it is important to handle animation cels with care. For film, the National Film Preservation Foundation's Film Preservation Guide: The Basics for Archives, Libraries, and Museums suggests working on a clean, flat, well-lit, ventilated, clutter-free work surface. Working at a clean and organized work station applies to all forms of good conservation work. Below I have gathered best known practices for handling and cleaning animation cels:

\footnotetext{
${ }^{94}$ Please see contact information in "Contacts and Resources."

${ }^{95}$ Richard W. Kroon, $A / V$ A to $Z$ an Encyclopedic Dictionary of Media, Entertainment and Other Audiovisual Terms (Jefferson, N.C.: McFarland \& Co, 2010), 46.
} 
- Clean the work surface every time before working with sensitive materials. Cels can easily pick up dust, dirt, hairs, and fibres. ${ }^{96}$

- Use a cleaner that will not leave residue, such as $99 \%$ isopropyl alcohol. ${ }^{97}$

- When handling film, wear cotton or nitrile gloves.

- Cotton gloves are reusable and gentle on delicate surfaces like cellulose; however, cotton gloves can snag on damaged, uneven cellulose or loose paint—use your best judgment to determine instances when cotton gloves should be avoided.

- Nitrile gloves have a smooth surface that inhibit accidental catching or tearing. Nitrile gloves also prevent foreign contaminants on the object from transferring to skin, such as chemicals or moulds. ${ }^{98}$

- If handling animation cels without gloves, do so with caution. Clean your hands thoroughly, and handle cels only by their edges to minimize the transfer of dirt, oils, and fingerprints.

- Handle animation cels and related artefacts as little as possible. Too much handling of any object, even in practiced hands, can cause damage over time.

- Avoid rolling, flexing, or bending the cel. ${ }^{99}$

- While wearing gloves, support cels by dispersing figures and hands evenly underneath the cel - always avoid touching painted areas.

- Do inspections with cels lying flat on a sterile surface.

\footnotetext{
${ }^{96}$ National Film Preservation Foundation, The Film Preservation Guide: The Basics for Archives, Libraries, and Museums (San Francisco, California: National Film Preservation Foundation, 2004). 20. ${ }^{97}$ Ibid.

${ }^{98}$ Rebecca A. Buck, Jean Allman Gilmore, and American Association of Museums, MRM5: Museum Registration Methods, fifth ed. (Washington, D.C.: The AAM Press, 2010), 224.

${ }^{99}$ Courvoisier Galleries, "Caring for Animation Art," S/R Laboratories Inc., accessed April 11, 2016, www.courvoisiergalleries.com/gallery-notes/73-caring-for-animation-art.html.
} 
- Large, awkwardly shaped, or fragile objects may require more than one handler. ${ }^{100}$

- If an animation cel has adhered to a layer of paper or another cel, seek professional advice from a conservator or from an institution experienced in the handling of animation cel art such as S/R Laboratories or Animation Art Conservation. ${ }^{101}$

- Prepare proper archival storage methods for animation cels before separating cels that have been stuck together.

- If attempting to separate adhered cels, it is advisable to detach a cel from a pencil test or other piece of paper by gently peeling, working slowly and patiently for best results. Remember to bend the paper and not the cel, working around the edges of the adhered portion of the object. $^{102}$

\section{Cleaning:}

- Professional cleaning must be done to remove any embedded oils, dirt, or light scratching. ${ }^{103}$

- To remove fingerprints, dust, smudges, or oil, clean the cel with a soft, clean flannel or cotton cloth. Wipe with light pressure in the same horizontal direction. ${ }^{104}$

- Never wipe or rub over painted or coloured areas of the cel.

- Never use liquid or compressed air near or on animation cels. Use of these cleansing tools may cause serious damage to the paint layers. ${ }^{105}$

\footnotetext{
${ }^{100}$ Rebecca A. Buck, Jean Allman Gilmore, and American Association of Museums, MRM5: Museum Registration Methods Fifth ed. (Washington, D.C.: The AAM Press, 2010), 224.

${ }^{101}$ Please see contact information in "Contacts and Resources."

${ }^{102}$ Chris Hoffmann, "The Care and Handling of Animation Cels," Rob Kelk's Anime Website, October 13, 1992, April 11, 2016, http://robkelk.ottawa-anime.org/hoffmann-faqs/cel_care.html.

${ }^{103}$ Courvoisier Galleries, "Caring for Animation Art," S/R Laboratories Inc., accessed April 11, 2016, www.courvoisiergalleries.com/gallery-notes/73-caring-for-animation-art.html.

${ }^{104}$ Ibid.
} 


\section{Housing}

Temperature and Relative Humidity (RH):

Mixed media objects present complications to the process of preserving an artefact. Paper, photographs, motion picture film, and fine art all have an existing history of preferred conservation practices. However, mixed media objects, like animation cels, do not necessarily have their own policies and procedures for preservation due to the combination of their individual materials. As cellulose degrades, it can become brittle, shrink, warp, curve or ripple causing the paint to crack or disengage from the cel (figures 2-4). ${ }^{106}$ On the other hand, as paint ages it can dry out and flake off. While we do not yet know what is best for the conservation of animation cels, it is important to store archival objects at consistent temperature and humidity levels. Fluctuating temperature and humidity levels can be far more destructive than controlled levels which may be more or less in favour of the plastic or the paint.

105 Ibid.

${ }^{106}$ Ron Barbagallo, “Mickey, Donald, Goofy \& Pluto What's Breaking Up That Old Gang of Mine?: A Quantitative Look at the 'Cel' Art Created for Walt Disney's Animated Films and Its Deterioration Process," Topics in Photographic Preservation 6 (1995): 102. 


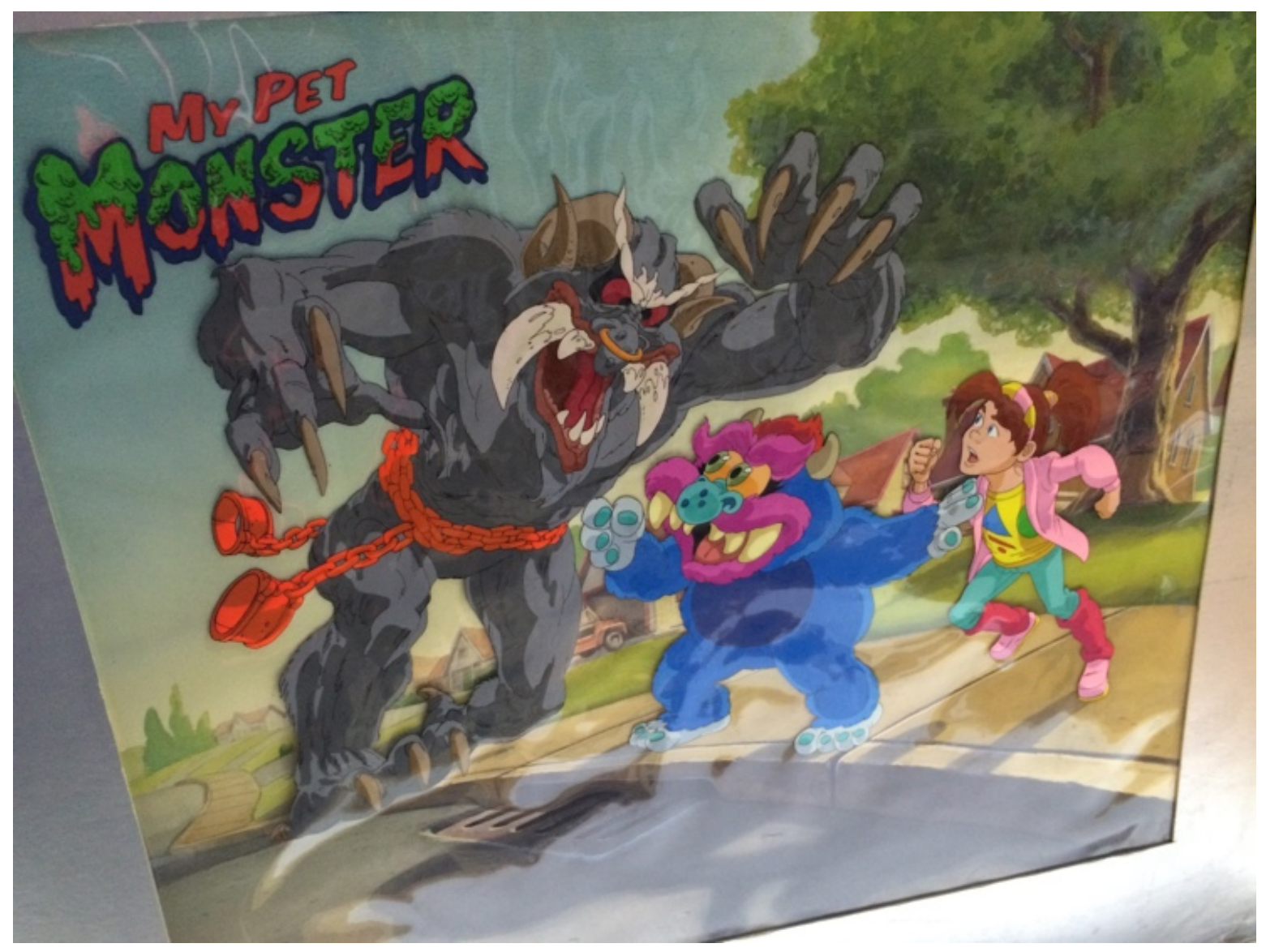

Fig. 2 - Framed animation cel and background art featuring characters from My Pet Monster (1987). As the acetate degrades, the cel begins to shrink and ripple. Image courtesy of Media Commons, University of Toronto Libraries. 


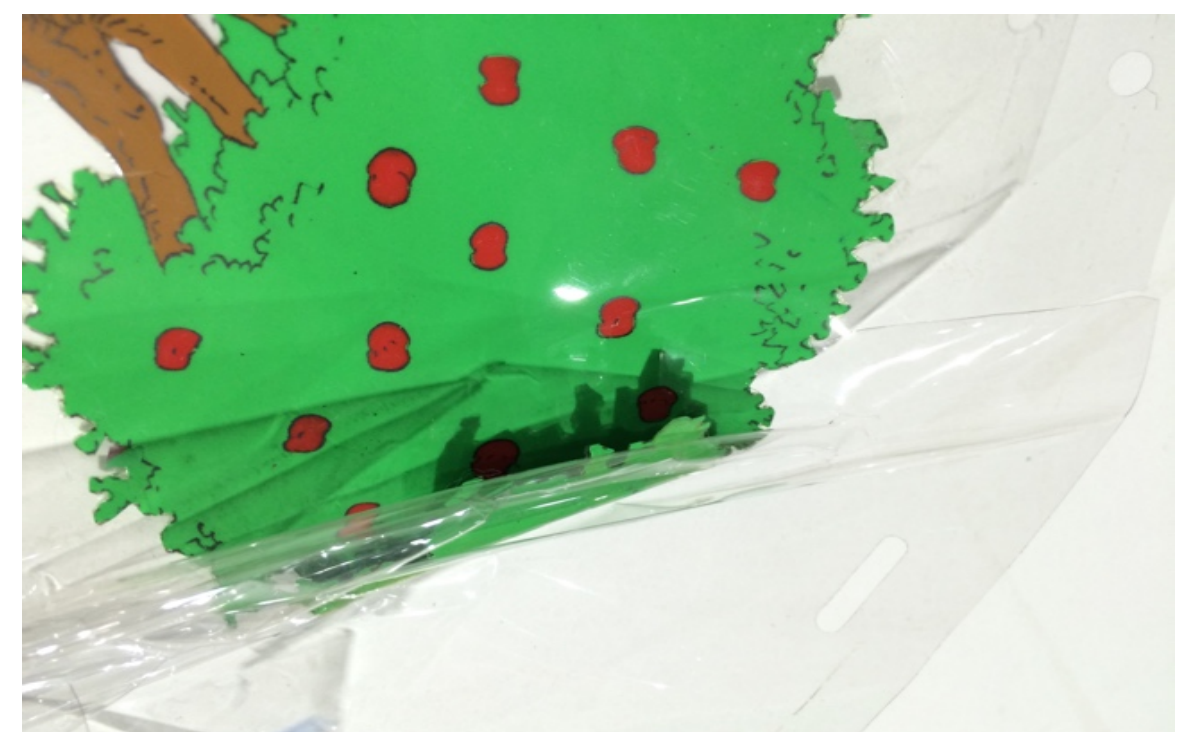

Fig. 3 - Due to folding and bending of the cel, the paint layer of the tree has started to lift from the cellulose acetate layer. Image courtesy of Media Commons, University of Toronto Libraries.

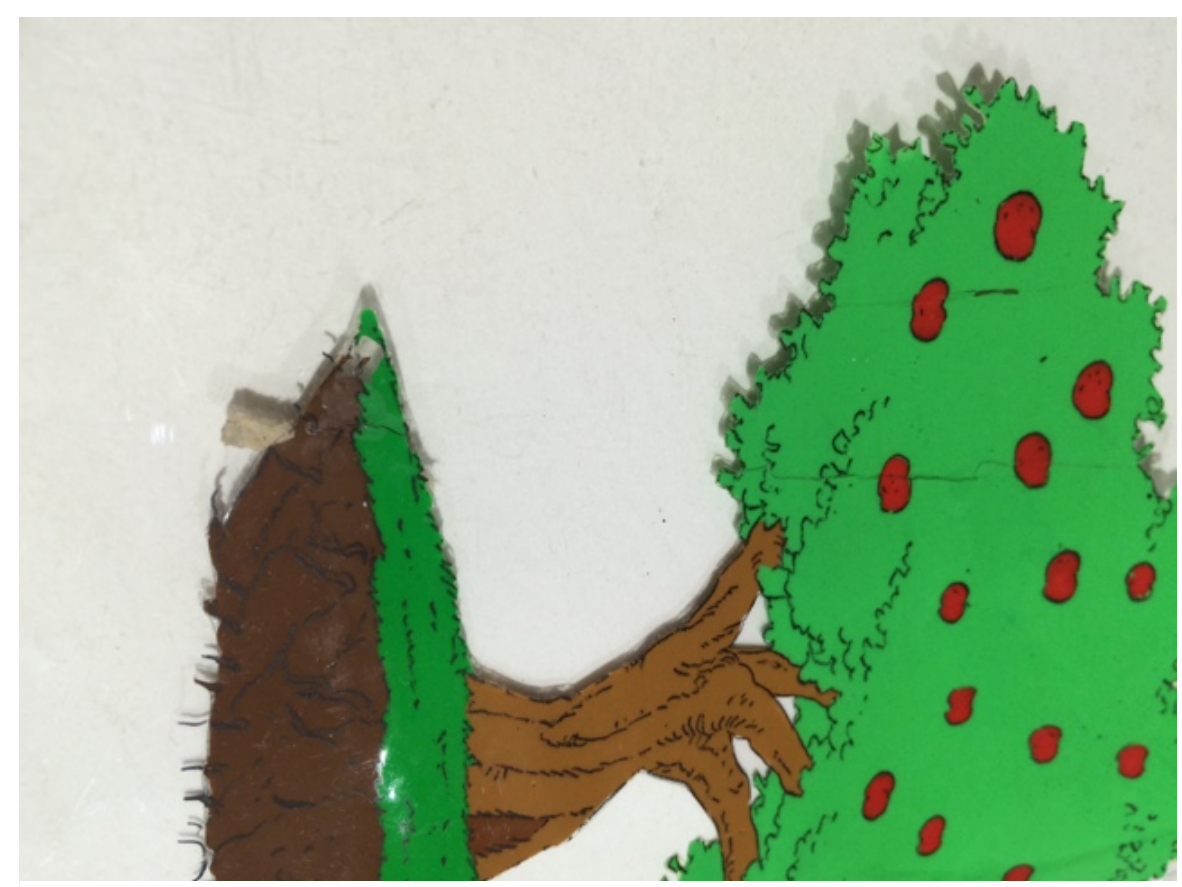

Fig. 4 - The apple tree from Rupert (1991-1997) shows how the paint layer can crack, chip, and flake. Pay special attention to the top edge of the ground and to the foliage of the apple tree. Image courtesy of Media Commons, University of Toronto Libraries. 
The science is simple; heat causes chemical reactions to occur faster. The colder the temperature, the slower vinegar syndrome and other forms of degradation are to develop. ${ }^{107}$ Many factors affect the ideal temperature and humidity levels for motion picture film. For example, the type of acetate base, colour stock versus black and white stock, and the level of any existing degradation. This is also true of acetate animation cels, with the exception of colour versus black and white. In general, to conserve acetate motion picture film, cooler temperatures between $5^{\circ} \mathrm{C}\left(41^{\circ} \mathrm{F}\right)$ and $-10^{\circ} \mathrm{C}\left(14^{\circ} \mathrm{F}\right)$ are preferable for relative humidity levels between $30 \%$ and $50 \% .{ }^{108}$ However, cold temperatures are not recommended for paint and paper storage. Low temperatures, which can delay plastic degradation for materials such as cellulose acetate, can also cause paint layers to dry out, crack, and chip. ${ }^{109}$ In "Animation Cels: Preserving a Portion of Cinematic History," authors Kristen McCormick and Michael R. Schilling disclose that the Disney Animation Research Library (ARL) currently stores their animation collection in $17^{\circ} \mathrm{C}$ $\left(62^{\circ} \mathrm{F}\right)$ to $18^{\circ} \mathrm{C}\left(65^{\circ} \mathrm{F}\right)$ at $50 \% \mathrm{RH} .{ }^{110}$ Without proper temperature and humidity control, contaminants such as mould can grow on paper objects, as well as cellulose acetate (figure 5). Until further research into animation cel preservation is complete, I recommend keeping animation cels under the same conditions as the $\mathrm{ARL}$, around $17^{\circ} \mathrm{C}\left(62^{\circ} \mathrm{F}\right)$ and $18^{\circ} \mathrm{C}\left(65^{\circ} \mathrm{F}\right)$ at $50 \%$ RH.

As part of a large university library, Media Commons has access to multiple storage locations featuring environmental controls. Currently, Media Commons' cold-storage motion

\footnotetext{
${ }^{107}$ James M. Reilly, "Instructions for Using the Wheel, Graphs, and Table Basic Strategy for Film Preservation," in IPI Storage Guide for Acetate Film, edited by Karen Santoro (Image Permanence Institute: 1996), 16.

${ }^{108}$ Peter Z. Adelstein, “IPI Media Storage: Quick Reference,” Image Permanence Institute, $2^{\text {nd }}$ ed. 2009.

${ }^{109}$ Kristen McCormick and Michael R. Schilling, “Animation Cels: Preserving a Portion of Cinematic History," Conservation Perspectives 29.1 (Spring 2014): 11. ${ }^{110}$ Ibid.
} 
picture film vault is kept at $7.2^{\circ} \mathrm{C}\left(45^{\circ} \mathrm{F}\right)$ with a relative humidity level of $25 \%$. The University of Toronto's DTL storage facility is kept at $17.2^{\circ} \mathrm{C}\left(63^{\circ} \mathrm{F}\right)$ with $40 \% \mathrm{RH}$ and a variation of only two degrees or two percent in either direction. I believe it is in the best interest of the Nelvana animation cels to be stored in the University of Toronto's DTL storage facility, where the temperature and humidity levels most closely resemble the levels maintained by the Disney Animation Research Library. However, in the future it may become necessary for some cels to be stored in the cold vault due to signs of degradation, such as yellowing, shrinkage, or waving.

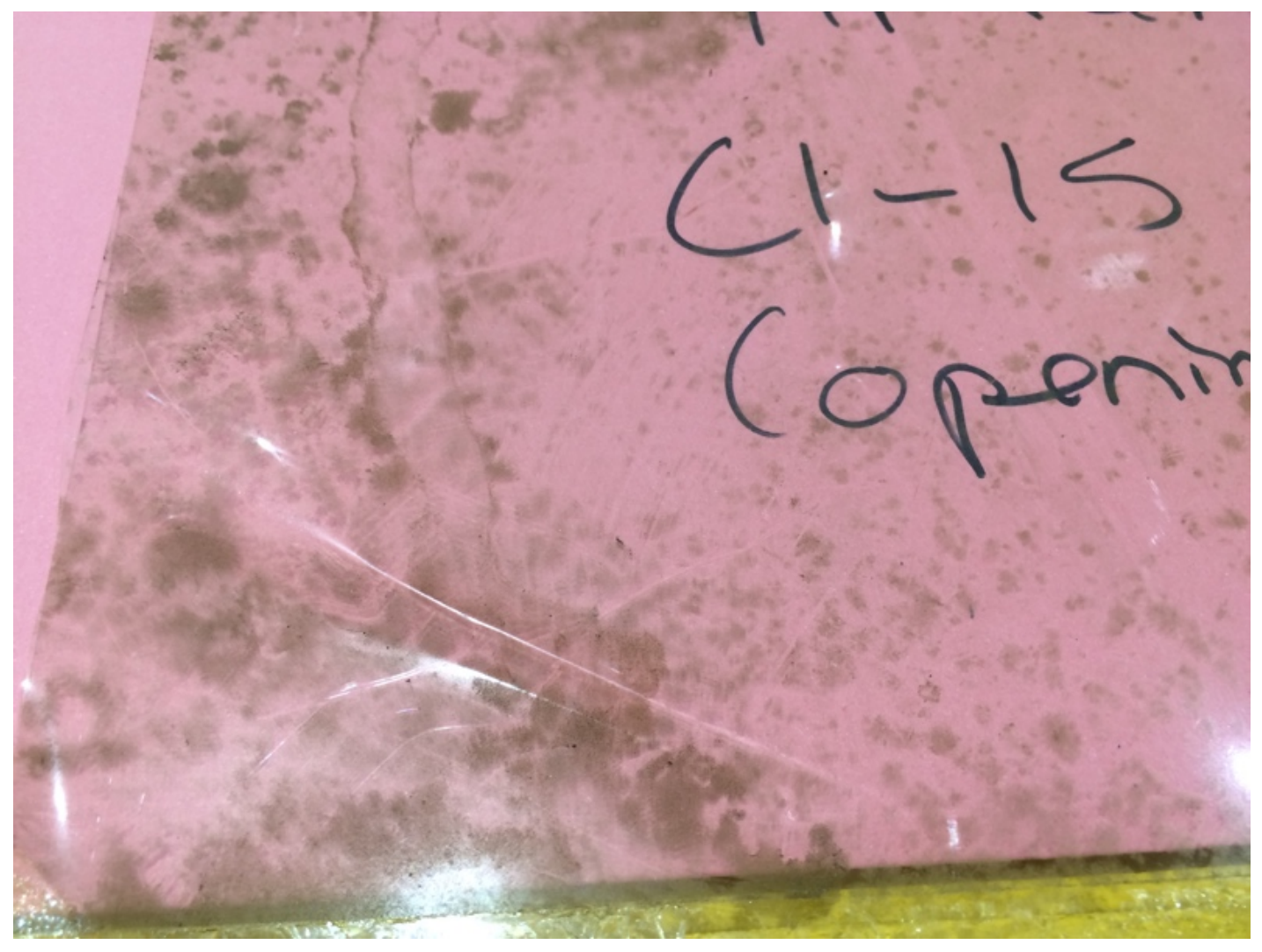

Fig. 5 - Opening credit cel from Mr. Pencil Draws the Line (n.d.) with mould growth and damage. Image courtesy of Media Commons, University of Toronto Libraries. 
Orientation:

Animation cels should be stored laying horizontal, as vertical storage of cels or other flat objects may result in curving or bending over time.

Volume:

Ideally, few animation cels should be stacked together. The care suggested by Courvoisier Galleries for animation cels indicates that no more than ten to fifteen cels should be stacked together. They further suggest that interleaving, with materials such as acid free paper, Mylar®, sheets of polypropylene, or MicroChamber ${ }^{\circledR}{ }^{111}$ interleaving paper, should be utilized between each cel. ${ }^{112}$ This recommendation does not include paper preservation. However, for reference, Courvoisier Galleries also suggests that any accompanying paper materials, such as line sketches or background art, should only have forty to fifty pages stacked together. ${ }^{113}$

As acetate can become quite delicate, even if it is still pliable, one should not bend, curl, or fold animation cels. This prevents chipping and cracking the paint. Compressed cels stacked with other objects like paper can cause paint layers to stick to or transfer paint to different nonarchival materials (figures 6-8). Horizontal storage and fewer cels stacked together allows for easier, safer access to materials.

\footnotetext{
${ }^{111}$ Karen Hong Saracino, "Animation Cel Storage and Preservation: Caring For a Unique American Art Form," (MA diss., John F. Kennedy University, 2006), 48-52.

${ }^{112}$ Courvoisier Galleries, "Caring for Animation Art," S/R Laboratories Inc., accessed April 11, 2016, www.courvoisiergalleries.com/gallery-notes/73-caring-for-animation-art.html.

${ }^{113}$ Ibid.
} 


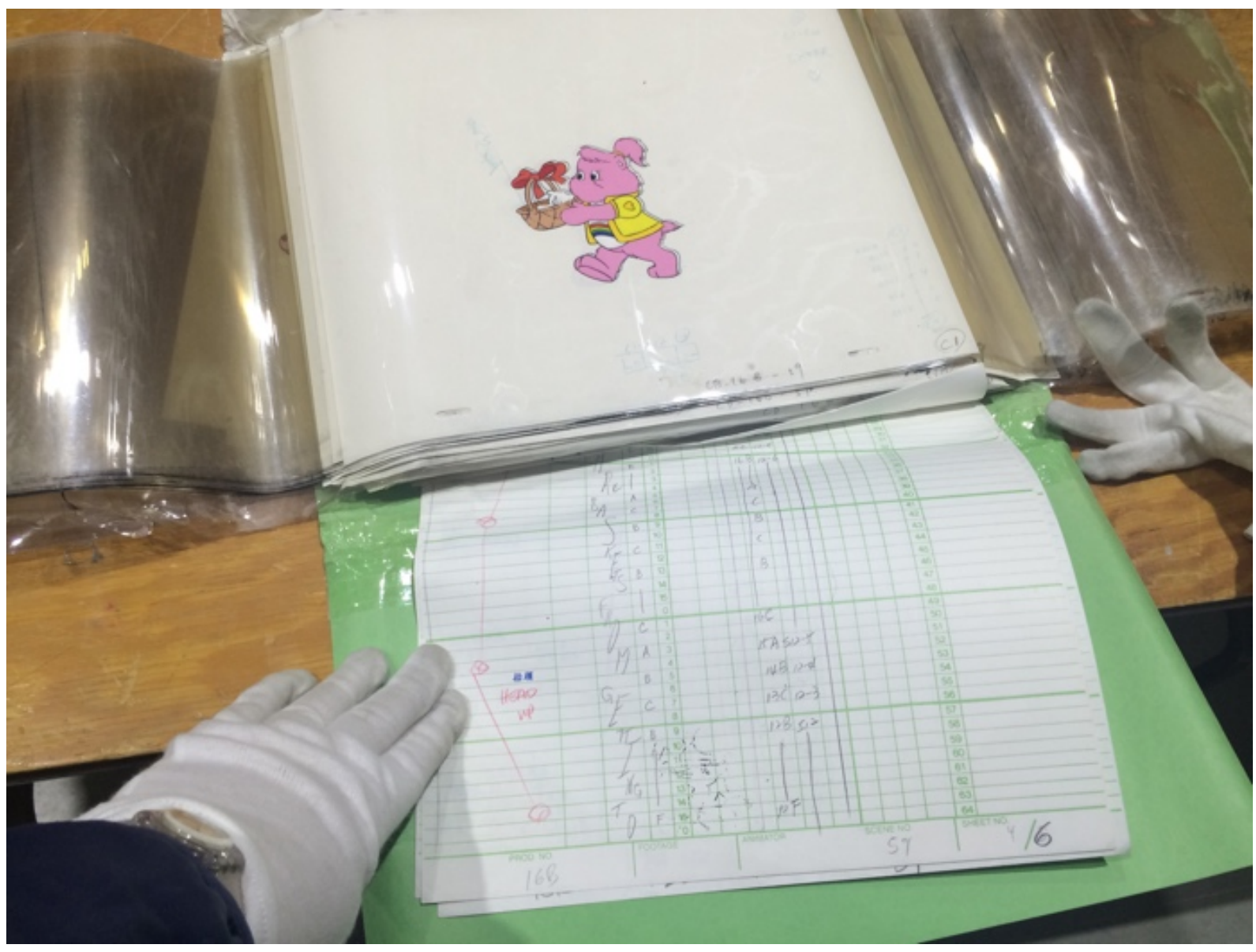

Fig. 6 - Paint Transfer: The Care Bears (1985-1988). The bold ink lines from Cheer Bear are now faded and have transferred from the cel to the dupe sheet below. Image courtesy of Media Commons, University of Toronto Libraries. 


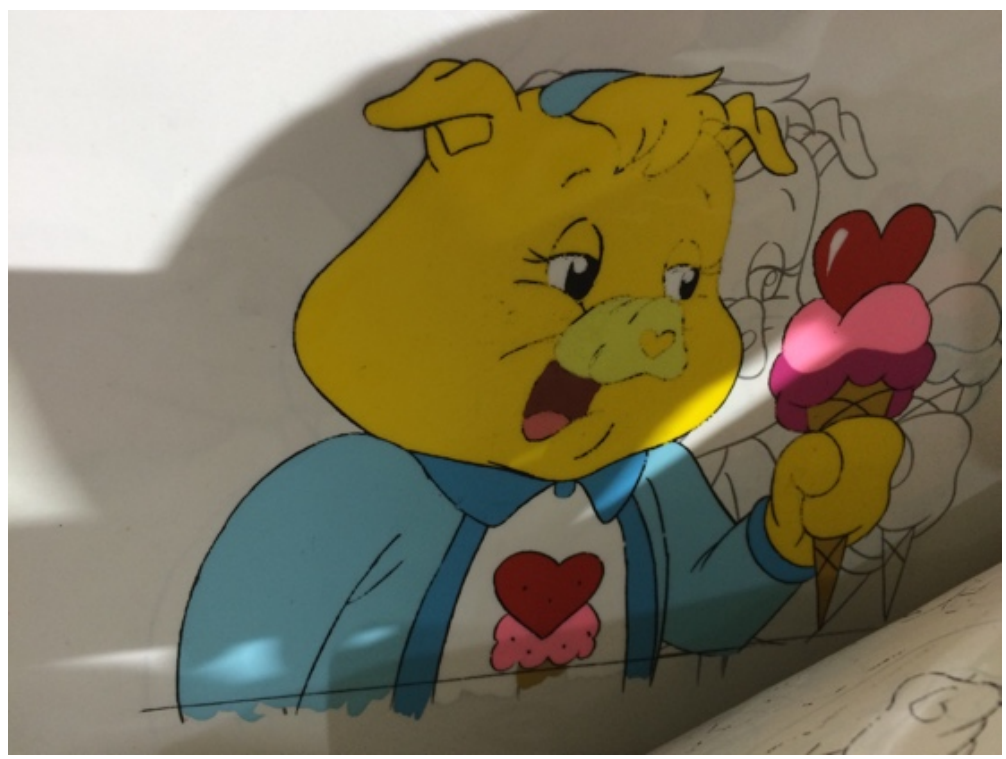

Fig. 7 - Paint Transfer: The Care Bears (1985-1988), close-up exemplifying the results of a paint transfer from a cel. Image courtesy of Media Commons, University of Toronto Libraries.

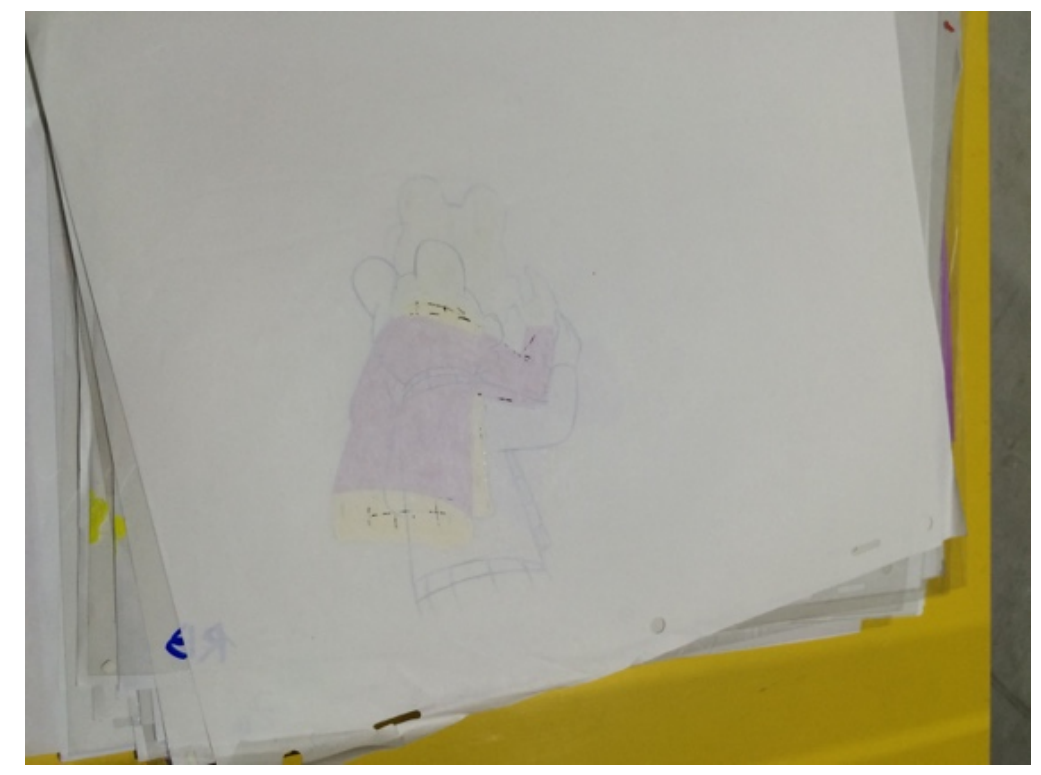

Fig. 8 - Paint Transfer: Rupert (1991-1997), close-up showing how ink has transferred to a pencil sketch placed above the cel. Image courtesy of Media Commons, University of Toronto Libraries. 


\section{Chapter 7: Storage Solutions}

The following are four different methods I have found currently used for animation cel storage and conservation. Each method has merits and disadvantages in terms of access, cost, and efficiency. The acting individual or organization looking to store animation cels should consider which method is best for a particular collection.

First, as recommended in "A Proposal for Equipment, Policies, and Procedures to Ensure the Safety of Nickelodeon's Assets in the New Archival Space," storing animation cels in Gaylord ${ }^{\circledR}$ 1-Compartment Archival Artifact Trays (figure 9) is ideal. ${ }^{114}$ To decrease the frequency of directly handling the cels and to maximize space, the authors also suggest storing a limited number of animation cels layered together within each tray. Trays can then be placed in a Gaylord Archival ${ }^{\circledR}$ Classic Record Storage Carton. This system will allow cels to be easily transported and stored (figure 10). ${ }^{115}$ Accession numbers and information can be placed on each tray within the box. ${ }^{116}$ One potential concern with this method is retrieving cels on the different layers of trays. Removing cels from the individual trays may require bending the tray or the cel when reaching down to pull the cels out.

\footnotetext{
${ }^{114}$ Katharine Allen, Caitlin Denny, and Jen O'Leary, “A Proposal for Equipment, Policies, and Procedures to Ensure the Safety of Nickelodeon's Assets in the New Archival Space," (MA diss., University of California, 2006), 10.

${ }^{115}$ Ibid.

${ }^{116}$ Ibid.
} 


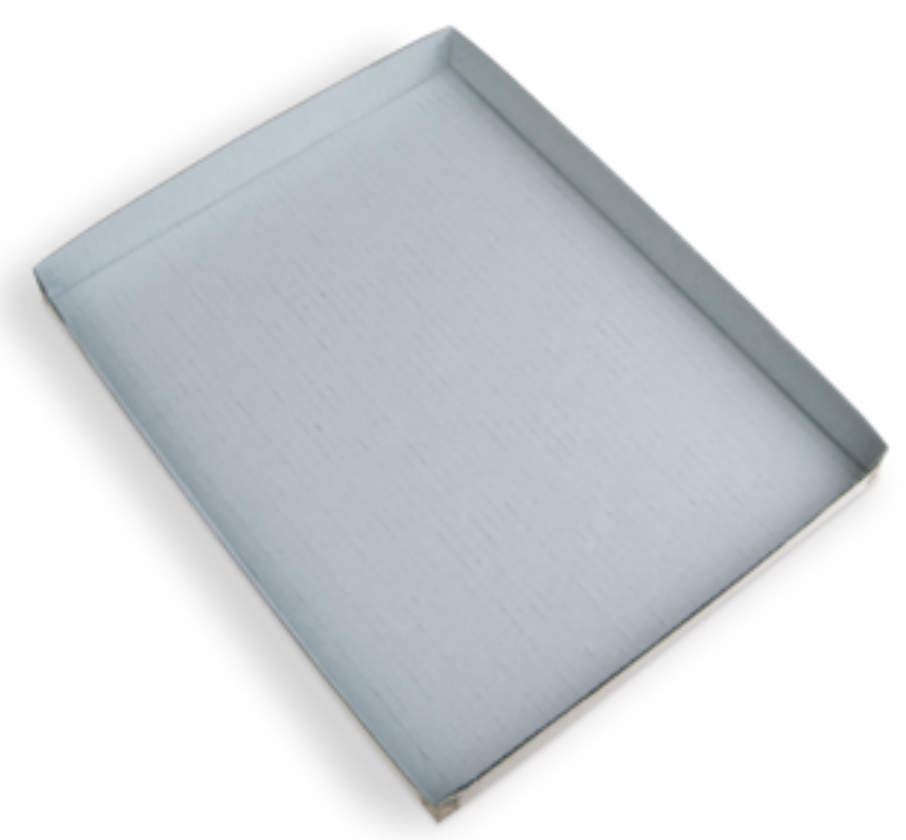

Fig. 9 - Gaylord® 1-Compartment Archival Artifact

Tray. The Archival Artifact Trays slide down into the

Classic Record Storage Cartons resting on the edges of the tray sitting below it, as opposed to compressing artefacts stored on each tray.

Fig. 10 - Archival ${ }^{\circledR}$ Classic Record Storage Carton with Handholds. 
In her paper, “Animation Cel Storage and Preservation: Caring For A Unique American Art Form," author Karen Hong Saracino suggests storing animation cels with mat boards, folders, or interleaves that contain zeolites. Products with zeolites, such as Conservation Resources International's MicroChamber ${ }^{\circledR}$ technology, are also called molecular traps or sieves. ${ }^{117}$ Hong Saracino identifies Nielsen \& Bainbridge's ArtCare ${ }^{\circledR}$ products as using MicroChamber ${ }^{\circledR}$ technology. ${ }^{118}$ Molecular sieves actively trap pollutants, effectively slowing down cel degradation and reducing yellowing and brittleness. ${ }^{119}$ For animation cel storage, Hong Saracino states:

Ideally, unframed animation cels should always be stored flat in a MicroChamber ${ }^{\circledR}$ mat board with a window cut-out. The cut-out window will allow several mat boards to be stacked on top of one another without ever putting pressure on the cel below. Matted cels can then be stacked on top of each other and placed in an acid-free box or, preferably, a MicroChamber ${ }^{\circledR}$ box. ${ }^{120}$

Any papers or boards used as molecular sieves will eventually need to be replaced. Due to the fact that these materials trap moisture and toxins, the frequency with which they would need to be replaced is entirely dependent on the strength of the molecular trap and the level of contaminants and humidity surrounding the object. ${ }^{121}$ For example, MicroChamber ${ }^{\circledR}$ papers and boards claim to have nearly one-hundred-seventy times the acid-removal capacity of other

\footnotetext{
${ }^{117}$ Karen Hong Saracino, "Animation Cel Storage and Preservation: Caring For a Unique American Art Form," (MA diss., John F. Kennedy University, 2006), 7-8.

${ }^{118}$ Ibid.

${ }^{119}$ Ibid.

${ }^{120}$ Ibid.

${ }^{121}$ Bertrand Lavédrine, Sibylle Monod, and Jean-Paul Gandolfo, A Guide to the Preventive Conservation of Photograph Collections (Los Angeles: Getty Publications, 2003), 52.
} 
molecular sieves. ${ }^{122}$ For 600 metres of $35 \mathrm{~mm}$ motion picture film stored at $21^{\circ} \mathrm{C}\left(70^{\circ} \mathrm{F}\right)$ with $75 \mathrm{~g}$

of zeolites authors Bertrand Lavédrine, Jean-Paul Gandolfo, and Sibylle Monod recommend renewal of molecular sieves every two to three years in their book, A Guide to the Preventive Conservation of Photograph Collections. ${ }^{123}$ Additionally, one should consider replacing molecular sieves every ten to fifteen years for the same type of film with the same amount of zeolites kept at $2^{\circ} \mathrm{C}\left(35^{\circ} \mathrm{F}\right) .{ }^{124}$ As the renewal of zeolite materials is entirely dependent on the objects at hand and their environmental storage conditions, the recommendations of Lavédrine, Gandolfo and Monod can be used as a frame of reference and applied in a general way to the renewal of zeolite materials stored with animation cels.

Adding molecular traps is most important to a collection if it is not possible to store the objects in a temperature- and humidity-controlled environment. The proper environmental conditions can drastically lower the amount of acids and moisture surrounding objects and reduce the need for molecular traps. As the proper environmental conditions to store animation cels is not yet known, I recommend the use of molecular traps to absorb any potentially harmful elements threatening cels. Molecular traps may also be used by institutions holding animation collections without any form of controlled storage facility. I recognize that to add in and replace traps involves the use of staff, time, and money. Utilizing zeolites may not be feasible for every institution; however, it is important to consider their benefits on a case by case basis. To save time replacing molecular sieves, I suggest renewing zeolite materials when re-inspecting the collection. This suggestion is explored further in Chapter 7: Next Steps.

\footnotetext{
${ }^{122}$ Conservation Resources International LLC., "MicroChamber," LLC, accessed August 6, 2016, http://www.conservationresources.com/Main/S\%20CATALOG/MicroChamber.htm.

${ }^{123}$ Bertrand Lavédrine, Sibylle Monod, and Jean-Paul Gandolfo, A Guide to the Preventive Conservation of Photograph Collections (Los Angeles: Getty Publications, 2003), 52.

${ }^{124}$ Ibid.
} 
A third option is to store animation cels in STiL Casing Solutions custom polypropylene boxes. ${ }^{125}$ This option was described to me through email correspondence with Kevin MacMillan, Manager, Burbank Operations Deluxe Archive Solutions. MacMillan is currently working on a project preserving acetate film sheets used in the printing of DC comic books. ${ }^{126}$ For this project the DC film sheets are placed in acid-free manila folders and stacked inside their custom-made STiL DC Comics Archival BOX@ (figures 11 and 12). Made of inert polypropylene, these boxes have been designed to stack and evenly distribute weight, up to twenty-five pounds. ${ }^{127}$ Promotional material for the product states that the box has been designed to insure ventilation, stabilize excess humidity, and protect from water and dust, as well as remain structurally stable for decades longer than cardboard boxes. ${ }^{128}$ The cases are $27.45 \times 20.28 \times 1.92$ inches, and at \$27.00 CAD per unit, this is the most expensive option (figure 13). Based out of Québec City, STiL Casing is an established Canadian company known for making high quality polypropylene cases for motion picture film and sound elements. The company can produce custom products or adjust existing products. $^{129}$

While the boxes are larger than required for most standard animation cels, STiL Casing can be contacted for an estimate on a bulk order of an adjusted STiL DC Comics Archival BOX. As polypropylene cans are the preferred storage container for motion picture film, I have determined the use of polypropylene to be ideal for animation cels in terms of ventilation, stability, and longevity. The two drawbacks to the use of polypropylene containers are their high

\footnotetext{
${ }^{125}$ Kevin MacMillan, Email interview, April 2016.

${ }^{126}$ Ibid.

${ }^{127}$ STiL Casing Solution, "STiL DC Comics Archival BOX," STiL Casing Solution, last modified December 2, 2011, accessed May 18, 2016, http://www.stilcasing.com/blog/wpcontent/uploads/2011/12/dc-comics-box-acetate-new.pdf.

${ }^{128}$ Ibid.

${ }^{129}$ To contact STiL Casing for a quote please use contact information provided in "Contacts and Resources."
} 
price and that they inhibit cel retrieval. The structured Polypropylene plastic cases do not have drop front capabilities, and therefore removing the cels from these containers may involve lifting or slightly curling the cel, which is generally ill advised. With few cels to a box, this storage method does not pose too high of a risk, but it is a factor to take into consideration. 


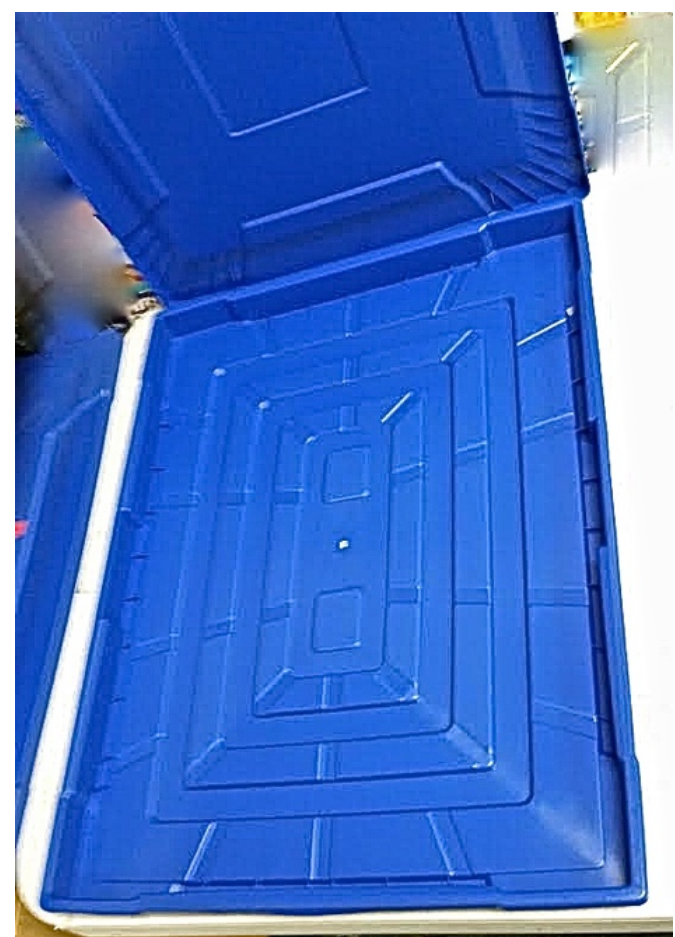

Fig. 11 - STiL DC Comics Archival BOX, open. Developed for DC comic book printing elements.

Photographs courtesy of Kevin MacMillan, Manager, Burbank Operations Deluxe Archive

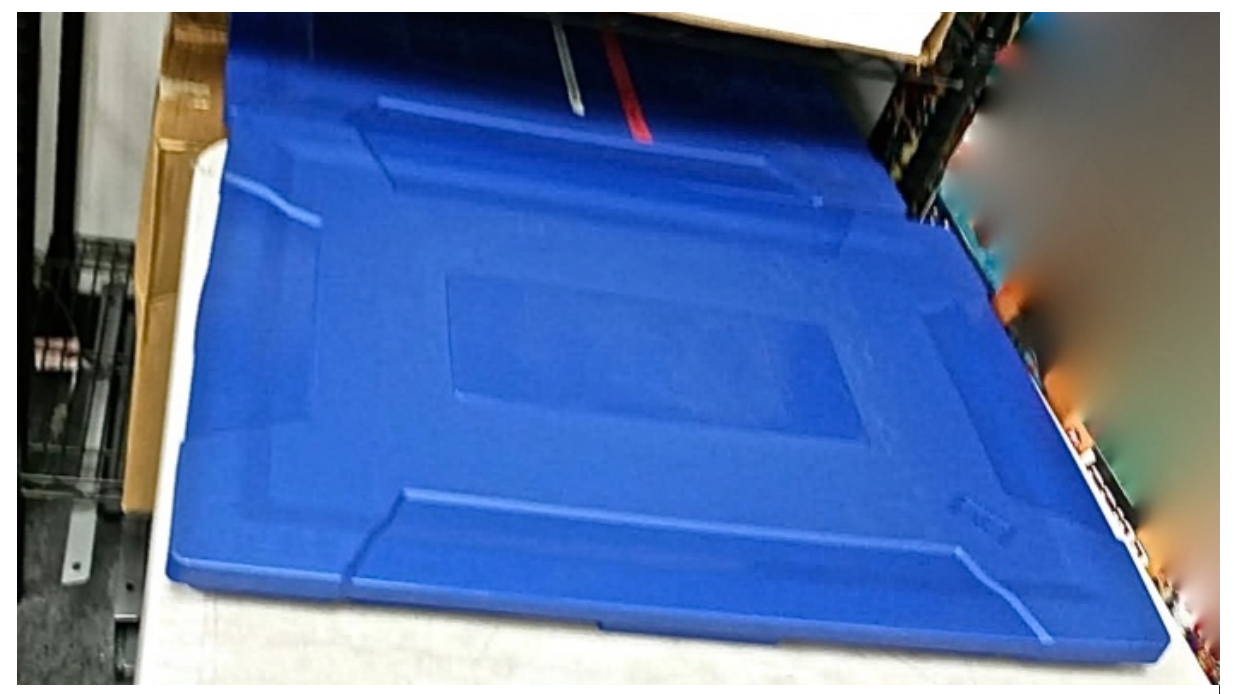

Fig. 12 - STiL DC Comics Archival BOX. Developed for DC comic book printing elements. Photographs courtesy of Kevin MacMillan, Manager, Burbank Operations Deluxe Archive Solutions. 


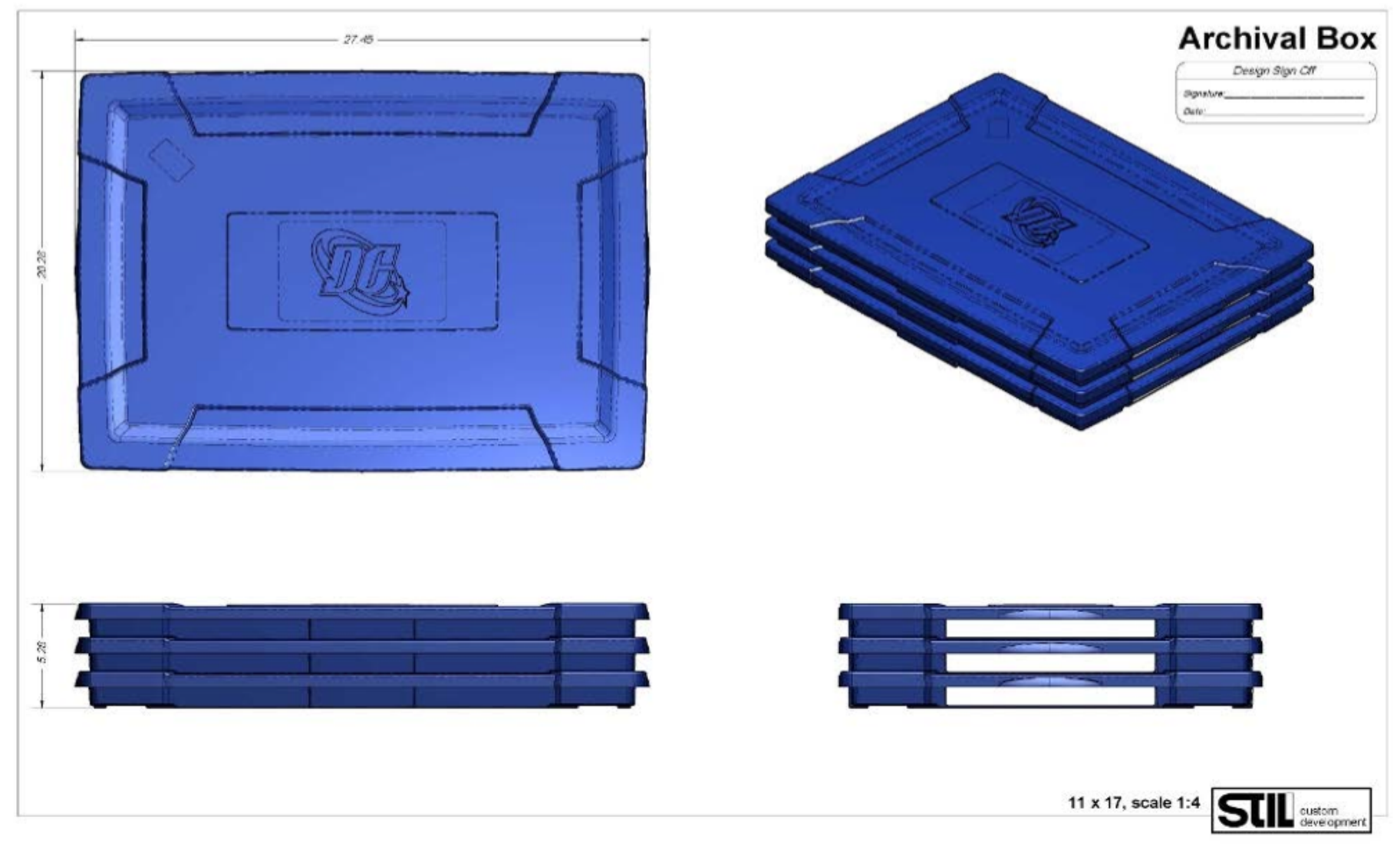

Fig. 13 - STiL Casing Solutions promotional materials released following the introduction of STiL DC Comics Archival BOXs, Kevin MacMillan, Manager, Burbank Operations Deluxe Archive Solutions. 
Lastly, it is also advisable to store cels in thin archival boxes from companies such as Hollinger Metal Edge. The boxes should measure the length and width of the cels, with approximately half a centimeter on either side. Leaving half a centimeter of space keeps cels from being compressed against the sides of the box, without leaving so much room that the cels could shift inside the box. Each box should be no higher than one to two inches. Hollinger offers a range of thin drop front storage boxes, including those that measure $12.5 \times 9.5 \times 1.5$ inches which cost between $\$ 8.20$ - $\$ 12.45$ USD depending on the number of boxes per order. Storing cels in shorter one-inch boxes saves space and discourages the storage of too many cels in each box. The height of the box should accommodate the number of cels and materials used as interleaving between cels. This option is certainly more affordable, and it is the most flexible in terms of accommodating animation cels of different sizes. Drop front boxes also provide an easier way of retrieving animation cels, eliminating the need to reach down and lift cels out of a box (figure 14). While Hollinger boxes do not have the same beneficial properties as polypropylene, cels can be more easily removed at a level angle.

Individual boxes create the ability to store cels where space is available. They also allow cels from the same production to remain stacked together as opposed to using trays in larger boxes, which might mean mixing or separating elements of the same production. Custom boxes allow for the most flexibility in terms of accommodating animation cels of different lengths such as background cels which can be over $100 \mathrm{~cm}$ (40 inches) long. For large flat objects, it may also be advisable to consider fine-art drawer storage units. While these units are large, heavy, and highly expensive, they provide secure storage and easy access to long, thin objects. Archives and museums use this kind of storage for large photographic prints, maps, unframed artwork, and architectural blueprints (figures 15-17). 


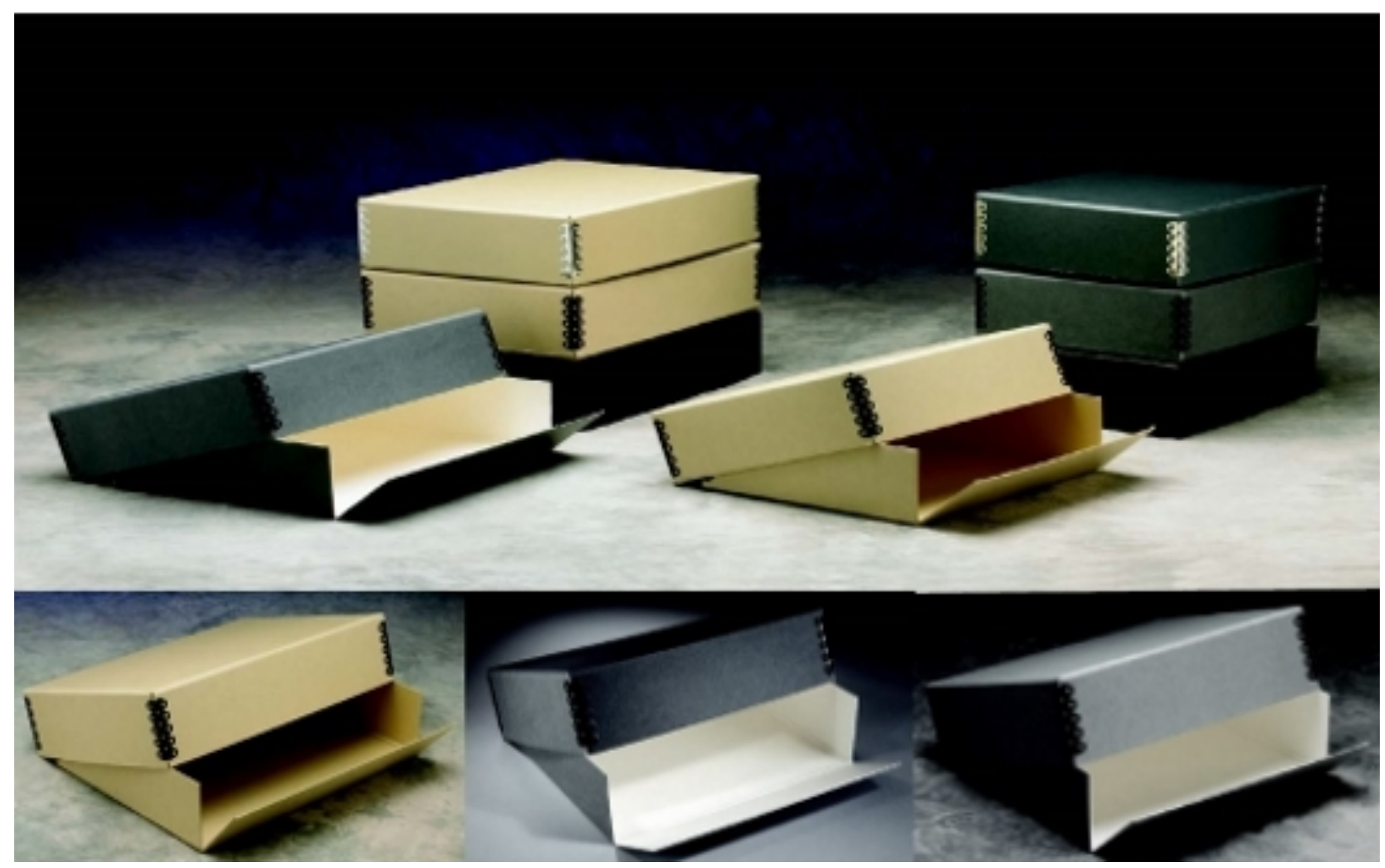

Fig. 14 - Hollinger Metal Edge range of Drop Front Boxes. These boxes feature one side that can drop flat after the lid is removed. Drop front boxes offer a distinct advantage for removing sensitive artefacts. Archival materials can be stored and retrieved safely without bending the object to remove it from a deep box. 


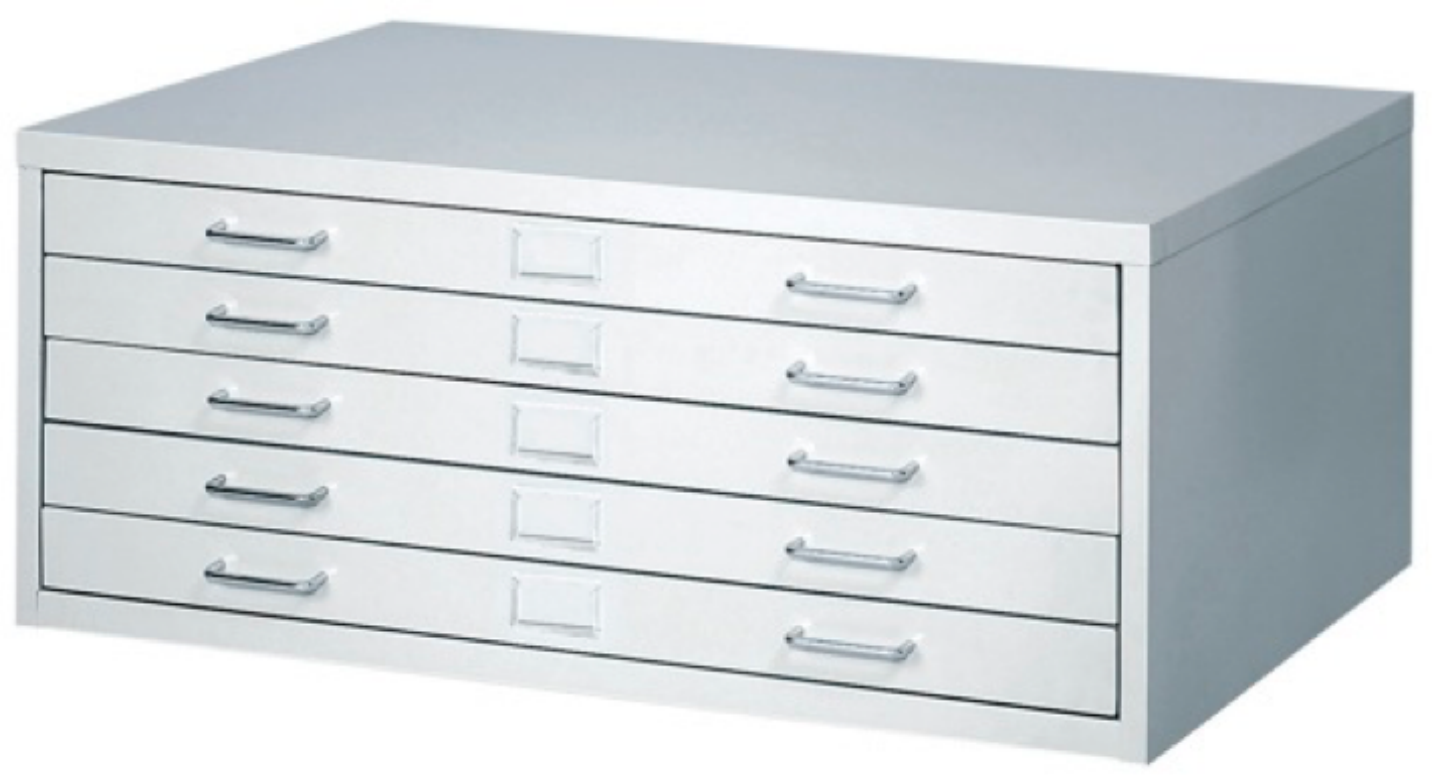

Fig. 15 - SAFCO Facil Steel Flat File-Small, five-drawer archival storage.

\section{Features}

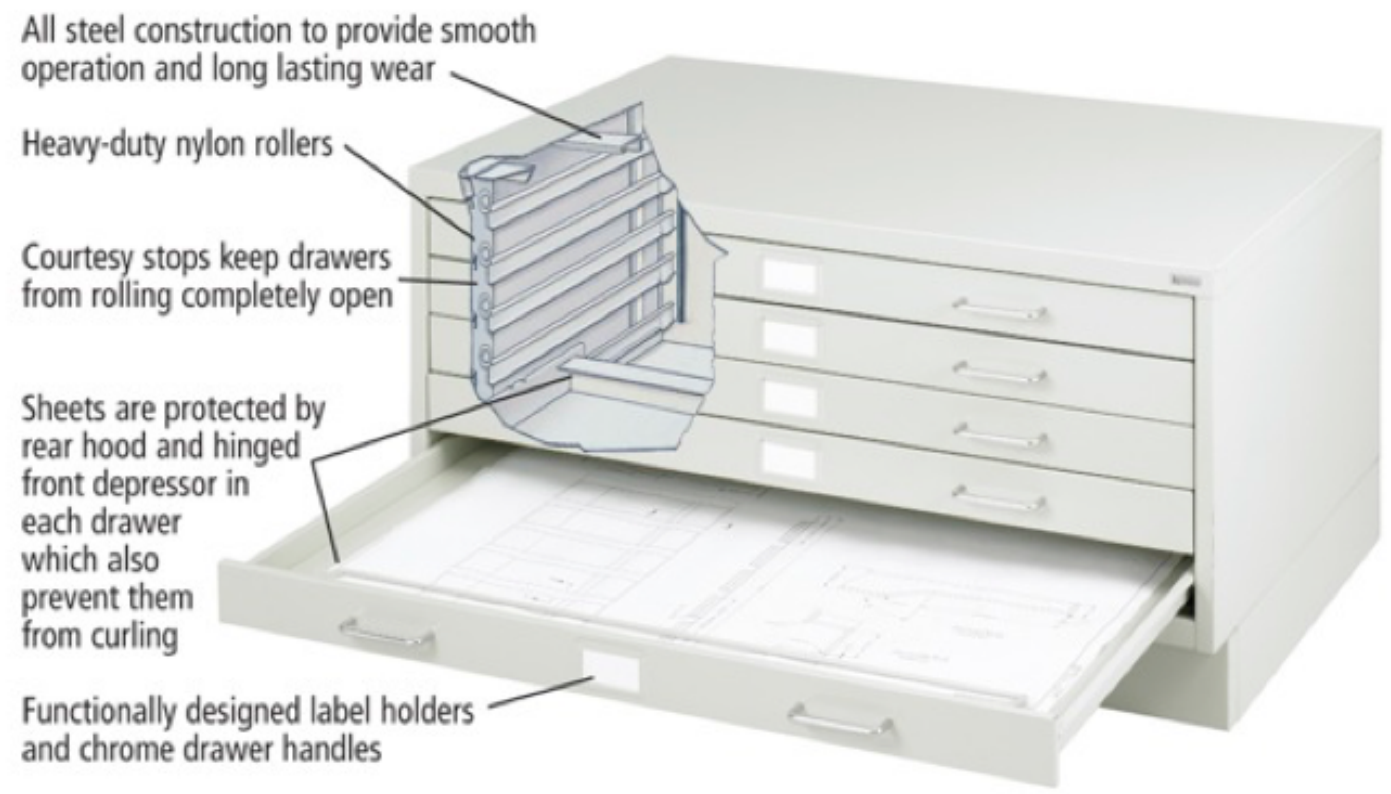

Fig. 16 - SAFCO image displays the many features of the SAFCO Facil Steel Flat File-Small unit. 


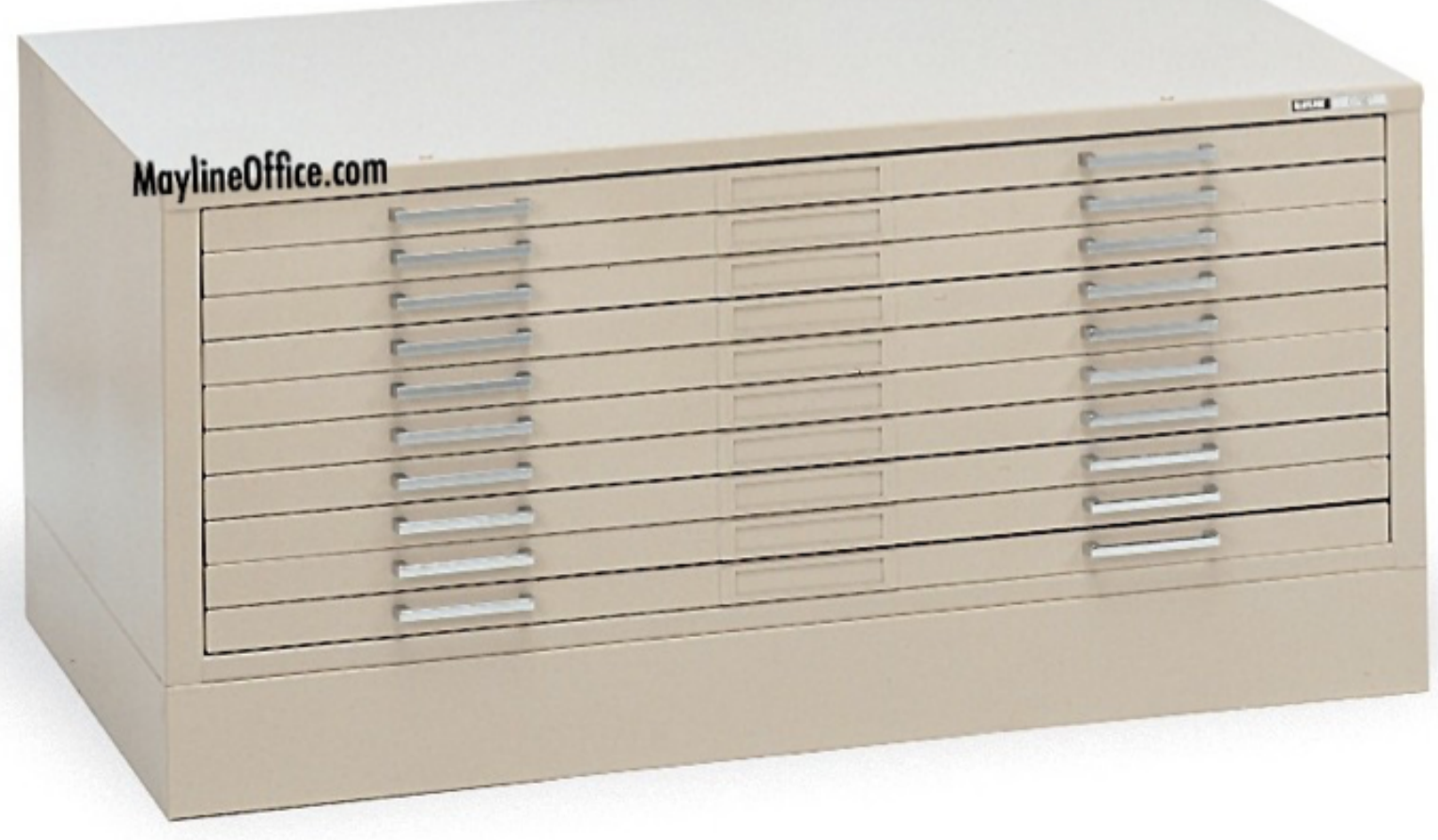

Fig. 17 - The Mayline 10-Drawer Steel C-File with Flush Base is an example of the same type of storage unit available with more drawers. 


\section{Storing Nelvana}

To remove the Nelvana animation cel folders from packing boxes, one short-term solution is to begin by relocating the folders to slightly smaller acid-free boxes. Smaller boxes allow for easier storage and fewer folders compressed together. Media Commons most frequently uses the Hollinger Record Storage Box, which is an acid-free sturdy double-layer box measuring $12 \times 15 \times 10$ inches. This box is a good size and will accommodate many of the folders, but not all. The Hollinger Oversized Record Storage Carton Box, measuring 15 x 24 x 10 , has a more accommodating width. However, the length of the box is too long for most of the folders that are only slightly longer than fifteen inches. The Hollinger Oversized box will be good for some of the slightly longer cels. For more uniquely shaped folders and loose cels, custom boxes will need to be ordered or constructed.

Due to the need to store limited numbers of animation cels together as well as the varying sizes of these cels, I believe that thin archival boxes are the best solution for more permanent Nelvana animation cel storage. This storage method allows for better organization and easy archival access. Individual boxes allow for the ability to store cels where space is available. They also allow cels from the same production to remain stacked together, as opposed to using trays in larger boxes, which might lead to mixing unrelated elements or separating elements of the same production. I have previously described two potential solutions for storing small numbers of cels in an organized and accessible way.

The first option is to use the aforementioned STiL DC Comics Archival BOX@. The second solution is to store cels in thin Hollinger Metal Edge archival boxes. This second option is more affordable, and it is the most flexible in terms of accommodating animation cels of different sizes. As mentioned previously, drop front boxes also provide an easier way of 
accessing animation cels, eliminating the need to reach down and lift cels out of a box. While Hollinger boxes do not have the same beneficial properties as polypropylene, cels can be more easily removed at a level angle.

Ultimately, it will be necessary to order custom sized archival boxes for longer cels and uniquely shaped cels. STiL Casing Solutions and Hollinger Metal Edge offer custom storage solutions; Media Commons has an existing relationship with both companies. To contact STiL Casing for a quote on custom products or for adjusting existing products, please use the contact information provided in "Contacts and Resources." 


\section{Chapter 8: Next Steps}

After accessioning a new object or collection, the next step is to monitor the collection. Effectively monitoring a collection includes regular inspection and detailed record keeping for quick reference and posterity. When inspecting film, archivists use a condition report as one means of record keeping. A condition report is a template that reflects the condition assessment of the object. Specific templates are chosen or created to accommodate the informational needs of the institution. The inspector can use a condition report to record signs of damage, decay, or change (figure 18). This record is useful when keeping track of an object's status. Because the previous report can be compared to future reports, any increases in decay or damage can then be easily identified. In my research I have not come across any kind of standardized condition report for assessing animation cels. Luke Sneyd, cataloguer of the Nelvana Collection for the AGO, included a customized information sheet with some pieces from the collection (figure 19). Archivists and collections managers can create their own animation cel condition report based on signs of yellowing, shrinkage, waving, and physical damage, such as scratches or tears. 


\section{Print Condition Report}

Collection/Title:

Length:

Black \& White

Color

Silent

Sound

Gauge:

Material:

Generation:

Triacetate
Positive

Diacetate

Polyester

Fine Grain

Reversal

Soundtrack Only

Image Only

Language/Head Titles/Intertitles/Subtitles:

\begin{tabular}{|c|c|}
\hline \multicolumn{2}{|c|}{$\begin{array}{l}\text { PhYSICAL DAMAGE } \\
\text { Marked on a scale of } 1 \text { (slight) to } 4 \text { (heavy) }\end{array}$} \\
\hline Emulsion Scratches & Projector Oil \& Dirt \\
\hline Base Scatches & Warpage \\
\hline Perforation Damage & Shrinkage \\
\hline Edge/Perforation Repair & Color Fading \\
\hline
\end{tabular}

Number of Splices:

Vinegar Syndrome (Acetate Decomposition Level)*

${ }^{*}$ Marked on a scale of 0 (no deterioration) to 3 (critical)

Notes:

Completed by

Date

Fig. 18 - The Film Preservation Guide: The Basics for Archives, Museums, and Libraries sample print condition report. A basic template to help identify and record the status of a film. 


\section{NELVANA 5000 \\ DATA SHEET}

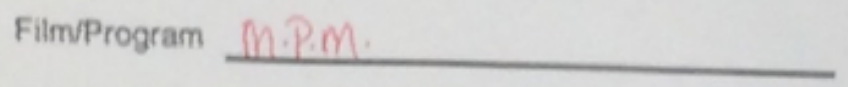

Episode \#

Element \# $1-12$

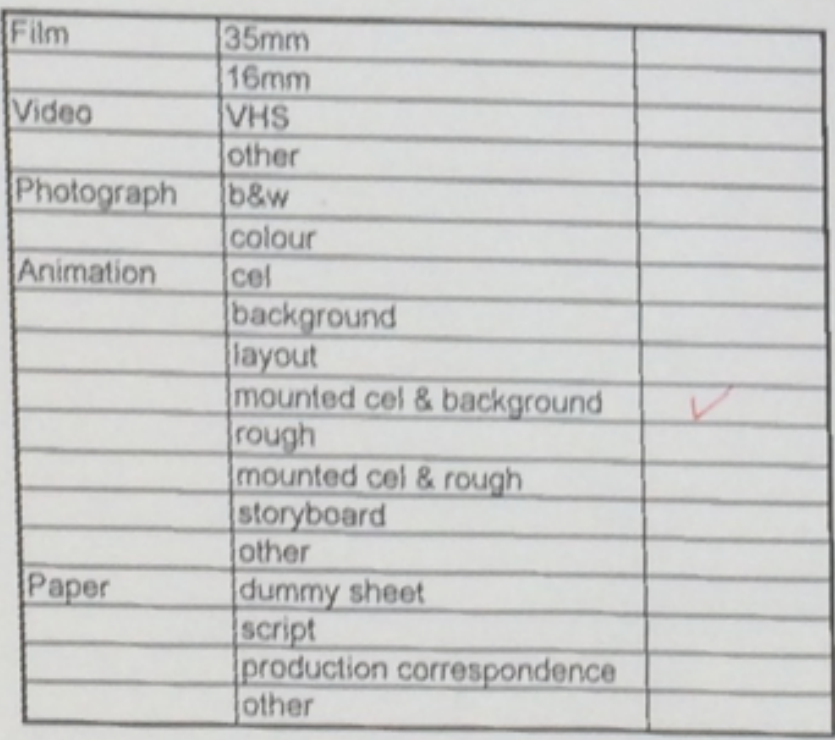

Description

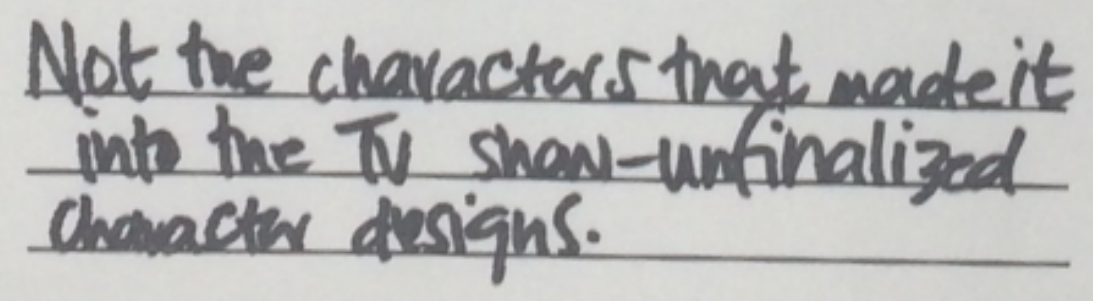

Originating Box

Current Box

\begin{tabular}{|l|l|}
\hline Condition & \\
\hline Excollent & wat \\
\hline Good & \\
\hline Poor & \\
\hline
\end{tabular}

\begin{tabular}{|l|l|}
\hline Dimensions & \\
\hline Height & vaviade \\
\hline Width & \\
\hline
\end{tabular}

\begin{tabular}{|l|l|}
\hline Duration & \\
\hline Length & \\
\hline
\end{tabular}

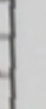

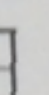
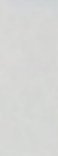

Dave 
In spite of a lack of defined inspection practices, one aid to animation cels conservation is a custom- or adjusted-condition report. A second tool, as described by both Schilling and Hong Saracino, is photography. Photographs of the object can be used for future comparisons when monitoring cels for changes in both the acetate and paint layers. ${ }^{130}$ Schilling recommends photographing animation cels over a light box to better see and document the cel over time. ${ }^{131}$

The length of time between inspection is dependent on the type of collection, the environment it is kept in, the existing condition of the materials, and resources available to the institution. Collections managers and archivists should inspect materials with existing symptoms of degradation more frequently for increased signs of decay. Ideally, degrading artefacts should be inspected every two to three years, and objects in good condition should be inspected approximately every five years. Frequent inspection allows institutions employing molecular sieves the opportunity to renew zeolite materials and track changes on a regular basis. However, in practice, inspections this frequent are not usually possible. Due to limited budgets, staff, time, and the ever increasing size of archival collections, it is more realistic to expect that a collection will be inspected every seven to ten years. I suggest monitoring the animation cels at least as often as films in the same collection or archive.

\footnotetext{
${ }^{130}$ Karen Hong Saracino, "Animation Cel Storage and Preservation: Caring For a Unique American Art Form," (MA diss., John F. Kennedy University, 2006), 68-69.

${ }^{131}$ Michael R. Schilling, Phone interview, June 14, 2016.
} 


\section{Chapter 9: Conclusion}

While researching the topic of animation cel preservation I have noticed a distinct lack of available resources. My observations have been corroborated by Hong Saracino's work. Hong Saracino identifies a divide in the dissemination of animation cel preservation information between private conservators and collections managers. Those most invested in long-term animation cel preservation are usually private collectors and conservators, as this is their business or personal interest. Current animation cel preservation research, advice, and experience is largely undisclosed in any formal sense or has been directed primarily at commercial conservators and private collectors. This makes it difficult for archivists and collections managers, who also care for animation cels, to access preservation methods or share their insight. ${ }^{132}$ Another gap in the information available on animation cel preservation is that it is geared mostly towards small collections of cels, as opposed to larger archival collections, such as the Nelvana collection. Using molecular traps and re-inspecting a collection every few years makes sense for small or private collections. However, for a collection comprised of thousands of cels, keeping all animation cels together and making frequent inspections is unfeasible. As we learn more about the preservation needs of celluloid and paints, it is important to keep in mind the diverse nature of these collections.

The information that I have gathered is a useful place to start when looking into the conservation of animation cel collections, suggested care, and possible storage solutions. I intended for this practical report to be used generally and as it applies to individual animation collections and their respective institutions. Eventually the recommendations and guidelines I

\footnotetext{
${ }^{132}$ Karen Hong Saracino, “Animation Cel Storage and Preservation: Caring For a Unique American Art Form," (MA diss., John F. Kennedy University, 2006), 69.
} 
have provided will need to be updated or adjusted as new information becomes widely available. It is important for the long-term preservation and care of the Nelvana Animation Collection that Media Commons continues to research information on animation cel preservation. In the future, those of us invested in animation cel preservation need to work collaboratively towards opening lines of communication and devising better preservation practices for animation cel collections of all sizes. 


\section{Contacts and Resources}

Animation Conservation:

$\underline{\text { S/R Laboratories Animation Art Conservation Center }}$

Office (818) 991-9955

Email help@srlabs.com

31200 Via Colinas, Suite 210

Westlake Village CA 91362

$\underline{\text { Animation Art Conservation }}$

Please address e-mails to one of the following:

Ron Barbagallo, director, Animation Art Conservation and director, The Research Library at

Animation Art Conservation

Greg Dyro, manager, The Research Library at Animation Art Conservation

Steve Bingen, head researcher, The Research Library at Animation Art Conservation

Ed Squair, special projects, The Research Library at Animation Art Conservation

$\underline{\text { www.animationartconservation.com }}$

rmb@animationartconservation.com

Storage:

Conservation Resources International, LLC

Phone: (800) 634-6932

Phone: (703) 321-7730

Fax: (703) 321-0629

E-mail: $\underline{\text { sales@,conservationresources.com }}$

5532 Port Royal Road 
Springfield, Virginia 22151

USA

Office Hours are 9:00 to 5:00 EST

$\underline{\text { STiL Casing Solutions }}$

General Information

418-694-0449 ext. 10

info@stilcasing.com

Sales and Customer Service

418-694-0449 ext. 11

sales@stilcasing.com

$\underline{\text { Hollinger Metal Edge }}$

6340 Bandini Blvd.

Commerce, CA 90040

USA

Phone: 800-862-2228 (CA) / 800-634-0491 (VA)

Fax: 888-822-6937 (CA) / 800-947-8814 (VA)

9401 Northeast Dr.

Fredericksburg, VA 22408

USA

Phone: 800-634-0491

Email: info@hollingermetaledge.com

There is an option to submit special requests on their website.

http://www.hollingermetaledge.com/special-requests.html 


\section{Bibliography}

Adelstein, Peter Z. “IPI Media Storage: Quick Reference," $2^{\text {nd }}$ Ed. Image Permanence Institute, 2009.

Allen, Katherine, Denny, Caitlin, O'Leary, Jen. “A Proposal for Equipment, Policies, and Procedures to Ensure the Safety of Nickelodeon's Assets in the New Archival Space.” Unpublished manuscript, University of California, Los Angeles, 2016.

American Institute for Conservation of Historic and Artistic Works. "Frequently Asked Questions.” American Institute for Conservation of Historic and Artistic Works. Accessed May 25, 2016. http://www.conservation-us.org/about-conservation/faq\#.V4kWi0JXk22.

Asquith, Kyle. "Hypercommercialism and Canadian Children's Television: The Case of YTV." Canadian Television: Text and Context. Waterloo, Ontario: Wilfrid Laurier University Press, 2011.

Barbagallo, Ron. "Mickey, Donald, Goofy \& Pluto What's Breaking Up That Old Gang of Mine?: A Quantitative Look at the 'Cel' Art Created for Walt Disney's Animated Films and Its Deterioration Process." Topics in Photographic Preservation 6 (1995): 98-105.

Bekkum, Herman van, Edith M. Flanigen, and J. C. Jansen. Introduction to Zeolite Science and Practice. Amsterdam: Elsevier, 1991.

Bertrand, Lavédrine, Monod, Sibylle, Gandolfo, Jean-Paul. A Guide to the Preventive Conservation of Photograph Collections. Los Angeles: Getty Publications, 2003. 52.

Blendon, Edith. "University Archives: A Reason for Existence." In The American Archivist 38, no. 2 (April 1975): 175-180.

Bredin, Marian, Henderson, Scott and Matheson, Sarah A. Television: Text and Context. Waterloo, Ontario: Wilfrid Laurier University Press, 2011. 
Buck, Rebecca A., Gilmore, Jean Allman, and American Association of Museums. MRM5:

Museum Registration Methods, $5^{\text {th }}$ ed. The AAM Press, American Association of

Museums, 2010.

Canadian Committee on Archival Description. Rules for Archival Description. rev. ed. Ottawa:

Bureau of Canadian Archivists, 2008.

Canadian Council of Archives. "Chapter 4: Graphic Materials.” In Rules for Archival

Description. rev. ed. Ottawa: Canadian Council of Archives and the National Archives of

Canada, 2008. 4-1 - 4-30.

Canadian Council of Archives. “Chapter 7: Moving Images.” In Rules for Archival Description.

Rev. ed. Ottawa: Canadian Council of Archives and the National Archives of Canada, 2008. 7-7 - 7-36.

Cavalier, Stephen. The World History of Animation. Berkeley, CA: University of California Press, 2011.

Courvoisier Galleries. "Caring for Animation Art.” S/R Laboratories Inc. Accessed April 11, 2016. www.courvoisiergalleries.com/gallery-notes/73-caring-for-animation-art.html.

Conservation Resources International LLC. “MicroChamber.” Accessed August 6, 2016.

http://www.conservationresources.com/Main/S\%20CATALOG/MicroChamber.htm.

Douglas, Frederic. “GC/MS Analysis.” Scientific Testimony, 2010. Accessed May 7, 2016.

http://www.scientific.org/tutorials/articles/gcms.html.

Fleming, Graham R. "Photochemical Reaction | Chemical Reaction.” Encyclopedia Britannica. Accessed April 25, 2015. http://www.britannica.com/EBchecked/topic/457736/ photochemical-reaction.

Fournier, Alban, Lavédrine, Bertrand, and Martin, Graham. Preservation of Plastic Artefacts in 
Museum Collection. Paris: Cths Edition, 2012.

Fitzgerald, James. "Nelvana 30th Anniversary Profile.” Kidscreen. Last modified May 1, 2001.

Accessed November 1, 2015. http://kidscreen.com/2001/05/01/30888-20010501/.

Glassman, Marc. "Three men and a bear: Nelvana at 25." The Free Library. 1996. Accessed

October 14, 2015. http://www.thefreelibrary.com/Three men and a bear: Nelvana at 25.$\underline{\mathrm{a} 030533629 .}$.

Getty Conservation Institute. “Overview.” The Getty. Accessed April 2, 2015. http:// www.getty.edu/conservation/about/overview.html.

Giachet, M.T., Schilling, Michael, Mazurek, Joy, Richardson, Emma, Pesme, C., Khanjian, Herant, Learner, Tom, and Kristen McCormick. "Characterization of Chemical and Physical Properties of Animation Cels from the Walt Disney Animation Research Library.” In ICOM-CC 17th Triennial Conference Preprints, Melbourne, 15-19 September 2014, ed. J. Bridgland, art. 1012, pp. 11, Paris: International Council of Museum, 2014.

Giachet, Miriam T., Schilling, Michael, McCormick, Kristin, Mazurek, Joy, Richardson, Emma, Khanjian, Herant, and Tom Learner. "Assessment of the Composition and Condition of Animation Cels Made from Cellulose Acetate.” Polymer Degradation and Stability 107 (Spring 2014): 223-230.

Gorman, G. E., S. J. Shep, and Chartered Institute of Library and Information Professionals. Preservation Management for Libraries, Archives and Museums. London, United Kingdom: Facet Publishing, 2006.

Harrison, Helen P. “Audiovisual Archives.” In Audiovisual Archives: A Practical Reader. United Nations Educational, Scientific and Cultural Organization, 1996. 1-9.

Hoffmann, Chris. "The Care and Handling of Animation Cels." Rob Kelk's Anime Website, 
October 13, 1992. Accessed April 11, 2016. http://robkelk.ottawa-anime.org/hoffmannfaqs/cel care.html.

Hollinger Metal Edge. "Drop Front Boxes.” Purpose Media, 2009. Accessed May 5, 2016. http://www.hollingermetaledge.com/modules/store/index.html? $\underline{\text { dept }=1 \& \text { cat }=336 \& \text { cart }=146703550525784189 .}$.

Hong Saracino, Karen. “Animation Cel Storage and Preservation: Caring for a Unique American Art Form.” MA diss., John F. Kennedy University, 2006.

Image Permanence Institute. User's Guide for A-D Strips: Film Base Deterioration Monitors, $2^{\text {nd }}$ ed., 2001.

IUPAC. Compendium of Chemical Terminology, $2^{\text {nd }}$ ed. Compiled by A. D. McNaught and A. Wilkinson. Blackwell Scientific Publications, Oxford (1997). XML on-line corrected version: http://goldbook.iupac.org (2006-); updates compiled by A. Jenkins. ISBN 09678550-9-8. doi:10.1351/goldbook.

Kroon, Richard W. A/V A to Z an Encyclopedic Dictionary of Media, Entertainment and Other Audiovisual Terms. Jefferson, N.C.: McFarland \& Co, 2010.

LaMarre, Thomas. “Animation Stand.” In The Anime Machine: A Media Theory of Animation, Minneapolis, MN: University of Minnesota Press, 2009. 12-25.

Lapointe, Frederic. "DC Comics - Acetate Box!.” STiL Casing Blog, December 2, 2011. Accessed May 18, 2016. http://www.stilcasing.com/blog/dc-comics-warner-bros-acetatebox.

Larson, Richard A., and Eric J. Weber. "Hydrolysis." In Reaction Mechanisms in Environmental Organic Chemistry, 103-167. Boca Raton: Lewis Publishers, 1994.

Macerola, Francois N., and Canada. Canadian Heritage. Canadian Content in the 21st Century in 
Film and Television Productions: A Matter of Cultural Identity. Hull, Quebec: Canadian Heritage, 2003.

MacMillan, Kevin. Email interview. April 2016.

Manco, Sara L., "Finding Wolff: Intellectually Arranging the Werner Wolff Fonds at the Ryerson Image Centre" (2012). Theses and dissertations. Paper 1264. 1-52.

Mazurkewich, Karen. Cartoon Capers: The History of Canadian Animators. Michigan: University of Michigan, 1999.

McAllister, Danielle, "A Tour Through Scotland: A Finding Aid of Scottish Travel Photography at the Archival \& Special Collections, University of Guelph" (2010). Theses and dissertations. Paper 1336. 1-88.

McCormick, Kristen, and Michael R. Schilling. "Animation Cels: Preserving a Portion of Cinematic History." Conservation Perspectives 29.1 (Spring 2014): 10-12.

National Film Preservation Foundation. The Film Preservation Guide: The Basics for Archives, Libraries, and Museums. San Francisco, California: National Film Preservation Foundation, 2004.

National Film and Sound Archive of Australia, The. "Technical Glossary // Restoration." National Film and Sound Archive. Accessed August 6, 2016. http://www.nfsa.gov.au/preservation/glossary/restoration.

Perlmutter, David. America Toons In: A History of Television Animation. North Carolina: McFarland and Company Inc., 2014.

Perron, Johanne. "The Use of FTIR in the Study of Photographic Materials." In Topics in Photographic Preservation 3 (1989): 112-122. 
Popart-highlights. "Home.” Accessed April 27. http://popart-highlights.mnhn.fr/index.html. Ramsey, Alexis E. et al. Working in the Archives: Practical Research Methods for Rhetoric and Composition. Carbondale: Southern Illinois University Press, 2010.

Reilly, James M. "Instructions for Using the Wheel, Graphs, and Table Basic Strategy for Film Preservation.” In IPI Storage Guide for Acetate Film, edited by Karen Santoro, 1-24. rev. ed. Image Permanence Institute, 1996.

Robinson, Chris. “English-Canadian Animation 1975 - 2000.” In English-Canadian Cinema since 1980. Edmonton: University of Alberta Press, 2002.

SAFCO. “Facil Steel Flat File-Small.” Safe Products Company, 2016. Accessed May 16, 2016. http://www.safcoproducts.com/facil-steel-flat-file-small-4969lg\#angleImage.

Schilling, Michael R. Phone interview. June 14, 2016.

Shashoua, Yvonne. "Inhibiting the Inevitable; Current Approaches to Slowing the Deterioration of Plastics.” In Macromolecular Symposia 238 (April 2006): 67-77.

STiL Casing Solution. "STiL DC Comics Archival BOX." STiL Casing Solution. Last modified December 2, 2011. Accessed May 18, 2016. http://www.stilcasing.com/blog/wp-content/ uploads/2011/12/dc-comics-box-acetate-new.pdf.

Stoffman, Daniel. The Nelvana Story: Thirty Animated Years. Toronto: Kids Can Press, 2002.

Strike, Joe. "From Disney to Ground Zero and Beyond - The Ron Barbagallo Interview," Animation World Network, January 31, 2011. Accessed May 17. http://www.awn.com/ blog/disney-ground-zero-and-beyond-ron-barbagallo-interview. VanderBurgh, Jennifer. “(Who Knows?) What Remains to Be Seen: Archives, Access, and Other Practical Problems for the Study of Canadian "National” Television.” In Canadian Television: Text and Context. Waterloo, Ontario: Wilfrid Laurier University Press, 2011. 
"thrift fax and fax jr. animation camera stands." American Cinematographer 56, no. (1 January, 1975).

Walsh, Betty. "Topics in Photographic Preservation." Identification of Cellulose Nitrate and Acetate Negatives by FTIR Spectroscopy 6 (1995): 80-97.

Wells, Paul. Understanding Animation. London; New York: Routledge, 1998. 